\title{
A transition of atmospheric emissions of particles and gases from on-road heavy-duty trucks
}

\author{
Liyuan Zhou ${ }^{1}$, Åsa M. Hallquist ${ }^{2}$, Mattias Hallquist ${ }^{3}$, Christian M. Salvador ${ }^{3}$, Samuel M. Gaita ${ }^{3}$, Åke Sjödin ${ }^{2}$, \\ Martin Jerksjö $^{2}$, Håkan Salberg ${ }^{2}$, Ingvar Wängberg ${ }^{2}$, Johan Mellqvist ${ }^{4}$, Qianyun Liu ${ }^{1}$, Berto P. Lee ${ }^{1}$, and \\ Chak K. Chan ${ }^{1}$ \\ ${ }^{1}$ School of Energy and Environment, City University of Hong Kong, Hong Kong, China \\ ${ }^{2}$ IVL Swedish Environmental Research Institute, Gothenburg, Sweden \\ ${ }^{3}$ Department of Chemistry and Molecular Biology, University of Gothenburg, Gothenburg, Sweden \\ ${ }^{4}$ Earth and Space Sciences, Chalmers University of Technology, Gothenburg, Sweden
}

Correspondence: Åsa M. Hallquist (asa.hallquist@ivl.se) and Chak K. Chan (chak.k.chan@cityu.edu.hk)

Received: 14 August 2019 - Discussion started: 4 September 2019

Revised: 20 December 2019 - Accepted: 10 January 2020 - Published: 12 February 2020

\begin{abstract}
The transition, in extent and characteristics, of atmospheric emissions caused by the modernization of the heavy-duty on-road fleet was studied utilizing roadside measurements. Emissions of particle number $(\mathrm{PN})$, particle mass $(\mathrm{PM})$, black carbon $(\mathrm{BC})$, nitrogen oxides $\left(\mathrm{NO}_{x}\right)$, carbon monoxide (CO), hydrocarbon (HC), particle size distributions, and particle volatility were measured from 556 individual heavy-duty trucks (HDTs). Substantial reductions in PM, $\mathrm{BC}, \mathrm{NO}_{x}, \mathrm{CO}$, and to a lesser extent $\mathrm{PN}$ were observed from Euro III to Euro VI HDTs by $99 \%, 98 \%, 93 \%$, and $57 \%$ for the average emission factors of $\mathrm{PM}, \mathrm{BC}, \mathrm{NO}_{x}$, and $\mathrm{CO}$, respectively. Despite significant total reductions in $\mathrm{NO}_{x}$ emissions, the fraction of $\mathrm{NO}_{2}$ in the $\mathrm{NO}_{x}$ emissions increased continuously from Euro IV to Euro VI HDTs. Larger data scattering was evident for PN emissions in comparison to solid particle number (SPN) for Euro VI HDTs, indicating a highly variable fraction of volatile particle components. Particle size distributions of Euro III to enhanced environmentally friendly vehicle (EEV) HDTs were bimodal, whereas those of Euro VI HDTs were nucleation mode dominated. High emitters disproportionately contributed to a large fraction of the total emissions with the highest-emitting $10 \%$ of HDTs in each pollutant category being responsible for $65 \%$ of total PM, $70 \%$ of total PN, and $44 \%$ of total $\mathrm{NO}_{x}$ emissions. Euro VI HDTs, which accounted for $53 \%$ of total kilometres driven by Swedish HDTs, were estimated to only contribute to $2 \%, 6 \%, 12 \%$, and $47 \%$ of $\mathrm{PM}, \mathrm{BC}, \mathrm{NO}_{x}$, and PN emissions, respectively. A shift to a fleet dominated by Euro
\end{abstract}

VI HDTs would promote a transition of atmospheric emissions towards low $\mathrm{PM}, \mathrm{BC}, \mathrm{NO}_{x}$, and $\mathrm{CO}$ levels. Nonetheless, reducing PN, SPN, and $\mathrm{NO}_{2}$ emissions from Euro VI HDTs is still important to improve air quality in urban environments.

\section{Introduction}

Vehicular emissions contribute significantly to gaseous and particle pollutants in the urban atmosphere, and descriptions of their extent and characteristics are key input components for urban air quality modelling. As technology and traffic demands change, so do the characteristics of the emissions. In Europe, the introduction of new legislation, especially Euro VI, has aimed to reduce emissions of many pollutants. Legislation exists for particles (mass and number) and selected gases; however, there are also many components of the emissions that are not directly regulated but are potentially detrimental to human health. The most notable example of a non-regulated pollutant is the abundance of ultrafine particles (UFP) (Campagnolo et al., 2019), defined as particles with a diameter less than $100 \mathrm{~nm}$ (Zhu et al., 2002). UFPs can cause lung disease, an increase of blood coagulability, and cardiovascular disease and related mortality (Du et al., 2016). In the most recent European emission standard (Euro class), this has partly been covered by introducing a limit on the solid particle number (SPN), while volatile particles and 
particles less than $23 \mathrm{~nm}$ are not considered. Furthermore, the legislation has mainly been based on test cycles performed before introducing a new engine into the market but only recently also off-cycle and in-service conformity testing has been introduced; hence, the actual performance in real traffic is less constrained, where driving pattern, maintenance, and age of the engine will vary. Here real-traffic studies may capture variability between vehicles and also put the effect of new legislation and parallel phaseout of older technology into perspective for the abatement of urban air pollution.

Heavy-duty vehicles (HDVs) usually account for a smaller number fraction of on-road vehicles than light-duty vehicles, but they tend to contribute to a disproportionately high fraction of mobile source particulate matter emissions (Gertler, 2005; Cui et al., 2017). Emissions from HDVs, often diesel, are significantly affected by the engine type, exhaust aftertreatment system (ATS), and driving conditions. The main purpose of an ATS is the reduction of particulate and gaseous pollutants. Diesel oxidation catalysts (DOCs) are used for reducing hydrocarbon emissions, selective catalytic reduction (SCR) systems or exhaust gas recirculation (EGR) is employed to mitigate $\mathrm{NO}_{x}$ emissions, and diesel particulate filters (DPFs) can reduce particulate matter mass emissions. The use of an ATS can, however, bring undesired side effects. For example, conversion of $\mathrm{SO}_{2}$ to $\mathrm{SO}_{3}$ and increased gaseous sulfuric acid formation have been reported from DOCs (Arnold et al., 2012). DPFs potentially enhance the formation of UFPs (Herner et al., 2011; Preble et al., 2017). Retrofitted DPFs can slightly reduce the $\mathrm{NO}_{x}$ emissions but significantly increase the direct emission of $\mathrm{NO}_{2}$ by as much as a factor of 8 (Smit et al., 2019). Failure of the temperaturedependent SCR in eliminating the excess $\mathrm{NO}_{2}$ leads to an elevated $\mathrm{NO}_{2}$-to- $\mathrm{NO}_{x}$ ratio (Herner et al., 2009; Bishop et al., 2010; He et al., 2015).

The Euro standard regulates vehicle emission limits in Europe. The Euro III standard was established in 1999, and more stringent Euro IV and Euro V standards were implemented in 2005 and 2008, respectively. The enhanced environmentally friendly vehicle (EEV) is a voluntary environmental standard which lies between the levels of Euro V and Euro VI. The currently enforced Euro VI standard has been implemented since 2013-2014 and introduced SPN limits into the regulation for the first time. Generally, newer engines are expected to perform better in controlling pollutant emissions. Guo et al. (2014) reported that Euro V diesel buses performed better than Euro IV and Euro III diesel buses in the emissions of all the pollutants, except for the generation of more nucleation mode particles. The latest 2018 European Environmental Agency (EEA) report confirms an overall improvement in the European air quality, while the road transport sector remains one of the major contributors to pollutant emissions and the largest contributor to the total $\mathrm{NO}_{x}$ emission (Grigoratos et al., 2019; EEA, 2018). A recent study based on an on-board sensor pointed out that HDVs emitted more than 3 times the $\mathrm{NO}_{x}$ certification standard dur- ing real-world hot-engine driving and idling operations (Tan et al., 2019). Published data regarding particle and gaseous pollutant emissions from real-world on-road Euro VI heavyduty vehicles are scarce and often limited by the small sample size (Giechaskiel et al., 2018; Grigoratos et al., 2019; Moody and Tate, 2017). Remote sensing sampling can measure a large sample size of vehicles but is usually restricted to gaseous pollutant emissions (Burgard and Provinsal, 2009; Burgard et al., 2006; Carslaw et al., 2011). From an air quality perspective, the particle emissions are crucial. The complexity and dynamics of atmospheric particles require detailed information of its emission for atmospheric modelling and for descriptions of their health impacts. For example, particle size is important to determine the effects on respiratory deposition in humans (Manigrasso et al., 2017; Lv et al., 2016).

Diesel exhaust particles are a complex mixture of numerous semi-volatile and non-volatile species, and the semivolatile compounds will experience gas-to-particle partitioning in the atmosphere (Robinson et al., 2007; Donahue et al., 2006). Biswas et al. (2009) reported that the semi-volatile fraction in HDV emissions is more oxidative than the refractory particles, which may change the redox state in cells and cause oxidative stress. Semi-volatile organic compounds, such as polycyclic aromatic hydrocarbons (PAHs) and their derivatives may possess genotoxic and carcinogenic characteristics (Bocchi et al., 2016; Vojtisek-Lom et al., 2015). Giechaskiel et al. (2009) suggested using the volatile mass fraction as a metric to assess health effects, as the volatile mass dissolves in the lung fluid and thereby interacts with epithelial cells. Deploying a volatility tandem differential mobility analyser in suburban Guangzhou, China, Cheung et al. (2016) found that $57 \%-71 \%$ of ambient particles between 40 and $300 \mathrm{~nm}$ contain volatile components. Furthermore, the evaporated semi-volatile compounds from the particle phase can be further oxidized to form secondary organic aerosols (SOAs) (Hallquist et al., 2009; Gentner et al., 2017, Liu et al., 2019). To better quantify the health effects and global and regional contributions of road traffic to the total particle burden in the atmosphere, information on the volatility properties of vehicle particulate emissions is needed.

Different approaches have been applied to study the emissions from heavy-duty trucks (HDTs; Franco et al., 2013). Chassis dynamometer tests provide relatively comprehensive emission characteristics of individual vehicles (Jiang et al., 2018; Chen et al., 2018; Thiruvengadam et al., 2015), but the artificial driving cycles make it difficult to simulate the full range of real-world driving conditions. Portable emission measurement systems (PEMSs) (Grigoratos et al., 2019; Pirjola et al., 2017) and plume-chasing studies (Lau et al., 2015; Pirjola et al., 2016) have been conducted in real-world environments, but they are often limited by small sample sizes. Tunnel studies ( $\mathrm{Li}$ et al., 2018) measure the average emission of all vehicles passing through the tunnel without specific emission information on vehicle types. Roadside mea- 
surements, as presented in this study, provide an opportunity to study real-world on-road traffic emissions on large sample sizes with individual-vehicle information (e.g. Hallquist et al., 2013; Dallmann et al., 2012; Carslaw and Rhys-Tyler, 2013; Watne et al., 2018).

In this work, we measured the gaseous and particle emissions from 556 on-road HDTs and quantified changes in emissions and the potential transition of characteristics caused by the reduction achieved by the introduction of more stringent Euro standards. Particle size distributions and particle volatilities were investigated with respect to Euro class, and pollutant emission characteristics were studied with respect to year of registration. Cumulative pollutant distributions were established to demonstrate the importance of controlling high emitters in reducing total emissions. The typical contribution of air pollution emissions from each Euro class HDTs was estimated based on total vehicle kilometres driven. Results of the presented pollutant emission factors in our study will be useful for both emission models and emission inventories. A clear transition of atmospheric pollutant emission trends was evident, and it can provide useful guidance for policies regarding the regulation of existing fleets.

\section{Methods}

\subsection{Field sampling site}

Pollutant emissions from HDTs were measured at a roadside location in Gothenburg, Sweden (Fig. 1). The HDTs passed the sampling location with an average speed of $27 \mathrm{~km} \mathrm{~h}^{-1}$ and acceleration of $0.7 \mathrm{~km} \mathrm{~h}^{-1} \mathrm{~s}^{-1}$ on a slight uphill slope $\left(\sim 2^{\circ}\right)$. Under such uphill driving conditions, vehicles are expected to emit higher levels of pollutants than during downhill and cruise driving. This will be further examined in Sect. 3.3.

\subsection{Air sampling}

The sampling of the emissions was conducted in line with Hallquist et al. (2013), i.e. extractive sampling of passing HDT plumes. Air was continuously drawn through a flexible copper tube to the instruments inside a container. A similar experimental set-up was previously applied to onroad bus emission measurements (Liu et al., 2019). Particles were measured by an EEPS (Engine Exhaust Particle Sizer ${ }^{\mathrm{TM}}$, model 3090, TSI Inc.) in the size range of 5.6$560 \mathrm{~nm}$ with high time resolution $(10 \mathrm{~Hz})$, while total particle number was measured by a butanol-based condensation particle counter (CPC, model 3775, TSI Inc., $50 \%$ cut-off diameter of $4 \mathrm{~nm}$ ). Particle numbers measured by the two instruments showed a good correlation $\left(R^{2}=0.73\right)$ (Fig. S1 in the Supplement). A second EEPS measured the outflow of a TD (thermodenuder, Dekati Ltd.), enabling estimations of particle volatility. The data were corrected for size-dependent losses in the TD. The temperature inside the TD heating zone was set to $250^{\circ} \mathrm{C}$ with a residence time of $\sim 0.6 \mathrm{~s}$, which is generally sufficient to evaporate nearly all the organics and sulfates from the particles (Huffman et al., 2008). However, organics with extremely low volatility (organic saturation mass concentration, $C^{*}<10^{-5} \mu \mathrm{g} \mathrm{m}^{-3}$ at $298 \mathrm{~K}$ ) may still be retained even at this high temperature (Gkatzelis et al., 2016). Thus, in this study, we define the "non-volatile components" as particle components that remain after passing through the TD operating at $250^{\circ} \mathrm{C}$. Differences in counting efficiencies between the two EEPS were accounted for by size-dependent correction factors (typically less than $10 \%$ ), which were retrieved by simultaneous sampling of ammonium sulfate particles by both EEPS instruments and direct comparison of their measured size distributions (Fig. S2). Black carbon (BC) and the mixture of $\mathrm{BC}$ and brown carbon $(\mathrm{BrC})$ were measured by an Aethalometer at 880 and $370 \mathrm{~nm}$, respectively (model AE33, Magee Scientific Inc.). The determination of particle mass concentrations by the integrated particle size distribution (IPSD) method requires information on particle density. Particle sphericity and unit density were assumed due to a lack of detailed knowledge about the chemical composition of the emitted particles. Figure S3 shows that there is a good linear relationship at $\mathrm{EF}_{\mathrm{PM}}$ values larger than $1 \mathrm{mg}(\mathrm{kg} \text { fuel })^{-1}$ between the BC mass measured by the Aethalometer and the non-volatile particle mass measured by the EEPS, but, assuming sphericity and unit density, the EEPS mass is lower, which indicates a potential underestimation of the effective non-volatile particle density. Compared to the EEPS, the detection limit of the Aethalometer is 5 times higher, which may influence the correlation between $\mathrm{BC}$ and particle mass (PM) at low mass loading conditions (Fig. S3). There have been several studies on the morphology and density of combustion-generated particles and its detailed dependence on combustion and dilution condition (e.g. Maricq and Ning, 2004; Ristimaki et al., 2007; Liu et al., 2009; Zheng et al., 2011; Quiros et al., 2015). However, to be consistent, and to compare with a majority of previously reported data, unity density was used for further discussion and comparisons. $\mathrm{CO}_{2}$ was measured by a non-dispersive infrared gas analyser (LI-840, LI-COR Inc.). $\mathrm{NO}_{x}$ and NO were measured simultaneously by two separate chemiluminescent analysers (model 42i, Thermo Scientific Inc.), and the $\mathrm{NO}_{2}$ concentration was calculated from the difference between the $\mathrm{NO}_{x}$ and $\mathrm{NO}$ concentrations. $\mathrm{SO}_{2}$ was measured by a pulsed fluorescence gas analyser (model 43c, Thermo Scientific Inc.). A remote sensing device (RSD) (OPUS Inspection Inc.) was used to measure the gaseous emission factors of $\mathrm{CO}, \mathrm{NO}_{x}$, and hydrocarbon (HC). Briefly, the instrument was set up with a transmitter and a receiver on the same side of the truck lane and a reflector on the opposite side. Colinear beams of infrared (IR) and ultraviolet (UV) light are emitted and cross-reflected through the plume, and light attenuation data related to respective pollutant concentrations are measured. Gas pollutant concentrations were determined relative to $\mathrm{CO}_{2}$ as measured by the RSD. $\mathrm{NO}_{x}$ and NO mea- 
(a)

(b)
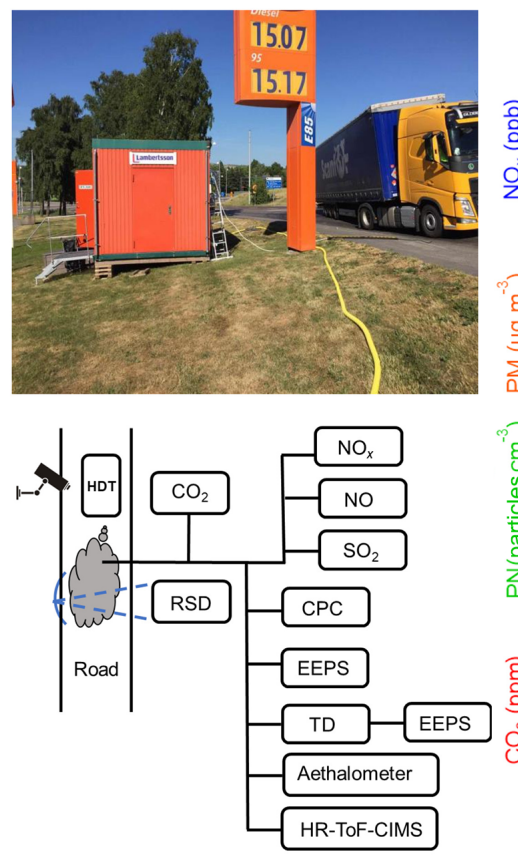

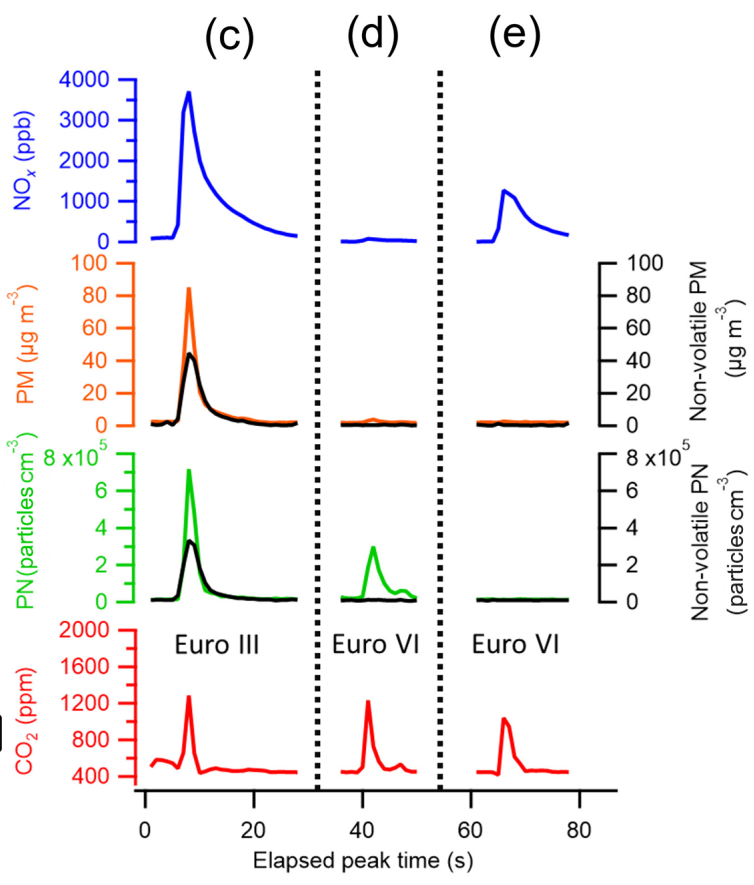

Figure 1. (a) Sampling site at the roadside in Gothenburg, Sweden, (b) schematic of the experimental set-up. HDT (heavy-duty truck), RSD (remote sensing device), CPC (condensation particle counter), EEPS (Engine Exhaust Particle Sizer ${ }^{\text {TM }}$ spectrometer), TD (thermodenuder), and HR-ToF-CIMS* (high-resolution time-of-flight chemical ionization mass spectrometer, the data from the HR-ToF-CIMS will be presented elsewhere) as well as examples of signals from three passing HDTs are shown. Concentrations of $\mathrm{CO}_{2}$, particle number (PN), non-volatile PN (black line), particle mass (PM), non-volatile PM (black line), and $\mathrm{NO}_{x}$ from (c) a typical Euro III HDT, (d) a typical Euro VI HDT, and (e) a Euro VI HDT with low PN emission are shown.

sured by the gas analysers and the RSD were in agreement $\left(R^{2}=0.53\right.$ and 0.66 , respectively; Figs. S4, S8a). The highresolution time-of-flight chemical ionization mass spectrometer (HR-ToF-CIMS) shown in Fig. 1 was used to characterize the chemical composition of organic and inorganic compounds in the gas and particle phases (emitted from the HDTs). However, the extensive chemical characterization is beyond the scope of this work and will be presented elsewhere.

A schematic of the experimental set-up is given in Fig. 1 along with some examples of typical temporal profiles of pollutant concentrations in the plumes from Euro III and Euro VI HDTs. A camera at the roadside recorded the HDT plate numbers, which were used for identification and to obtain engine Euro type information. All the instruments were at least operated at $1 \mathrm{~Hz}$ sampling frequency to capture rapidly changing concentrations during the passage of a HDT, which is sufficiently fast to measure pollutant concentration peaks (typically 5 to $20 \mathrm{~s}$ in duration) as shown in Fig. 1c-e. In general, the duration of a peak was around $5 \mathrm{~s}$. It was slightly longer for $\mathrm{NO}_{x}$ (around 20s), which limits measurements of high-frequency passages. Euro III HDTs typically emitted a significant PN, $\mathrm{PM}, \mathrm{NO}_{x}$, and non-volatile components (Fig. 1c). More than $95 \%$ of Euro III, Euro IV, Euro V, and EEV HDTs had measurable particle emission signals. Signif- icant differences in low particle and gaseous emissions were evident for Euro VI HDTs (Fig. 1d and e).

\subsection{Data analysis}

The exact time of individual HDTs passing the sampling inlet was determined from the camera recordings, and the associated plume pollutant concentrations were integrated to calculate corresponding pollutant emission factors of individual HDTs as described by Hallquist et al. (2013). Emissions of gases and particles from individual HDTs were normalized by the $\mathrm{CO}_{2}$ concentration to compensate for different degrees of dilution during sampling (Janhäll and Hallquist, 2005). $\mathrm{CO}_{2}$ peak concentrations exceeding 4 times the standard deviation of the background signal were used as the base criterion for successful plume capture. Peaks in $\mathrm{NO}_{x}, \mathrm{PN}$, $\mathrm{PM}$, and $\mathrm{BC}$ concentrations concurrent with that of $\mathrm{CO}_{2}$ signify the presence of co-emitted pollutants in a HDT plume. Emission factors (EFs) of gaseous and particle emissions for individual HDTs can then be expressed in units of amount of pollutant emitted per kilogram fuel burned based on the carbon balance method (Ban-Weiss et al., 2009; Hak et al., 2009):

$$
\mathrm{EF}_{\text {pollutant }}=\frac{\int_{t_{1}}^{t_{2}}\left([\text { pollutant }]_{t}-[\text { pollutant }]_{t_{1}}\right) \mathrm{d} t}{\int_{t_{1}}^{t_{2}}\left(\left[\mathrm{CO}_{2}\right]_{t}-\left[\mathrm{CO}_{2}\right]_{t_{1}}\right) \mathrm{d} t} \times \mathrm{EF}_{\mathrm{CO}_{2}},
$$


where $\mathrm{EF}_{\text {pollutant }}$ is the emission factor of the respective pollutant. The time interval of $t_{1}$ to $t_{2}$ represents the period when the instruments measured the concentration of an entire pollutant peak from an individual HDT (see Fig. 1c-e). Dallmann et al. (2012) and Preble et al. (2015) used the concepts of inflection points to identify $t_{1}$ and $t_{2}$. In our study, $t_{1}$ and $t_{2}$ were determined similarly: $t_{1}$ is the point before the pollutant concentration intensity increases abruptly and $t_{2}$ is when the intensity becomes relatively flat and undistinguishable compared to background levels. It is noted that the integrated peak intensity is insensitive to the exact location of $t_{2}$ since the added integrated signals at or beyond this point are fluctuating around zero. $t_{1}$ and $t_{2}$ were determined independently of each pollutant peak to account for differences in the time response of individual instruments to the exhaust plume. $\int_{t_{1}}^{t_{2}}\left([\text { pollutant }]_{t}-[\text { pollutant }]_{t_{1}}\right) \mathrm{d} t$ and $\int_{t_{1}}^{t_{2}}\left(\left[\mathrm{CO}_{2}\right]_{t}-\left[\mathrm{CO}_{2}\right]_{t_{1}}\right) \mathrm{d} t$ are the changes in concentration of a pollutant and $\mathrm{CO}_{2}$, respectively, during this time interval. $\mathrm{EF}_{\mathrm{CO}_{2}}$ of $3158 \mathrm{~g}(\mathrm{~kg} \text { diesel fuel })^{-1}$ was used as the emission factor of $\mathrm{CO}_{2}$, assuming complete combustion and a carbon content of $86.1 \%$ as given in Edwards et al. (2014). Emission factors for plumes with pollutant concentrations lower than our set detection limit (4 times the standard deviation of the pollutant background signal) were replaced by the minimum value among all recorded emission factors $\left(\mathrm{EF}_{\min }\right)$ rather than being omitted to avoid inflating emissions from low-emitting HDTs.

\section{Results and discussion}

\subsection{Fleet compositions}

A total of 675 resolved plumes from 556 individual HDTs for the carriage of goods with weights exceeding $12 \mathrm{t}$ were identified. There were 330 Swedish HDTs with Euro type information, 46 Swedish HDTs from which Euro type information was not available, and 180 foreign-licensed nonSwedish HDTs. Among the 330 Swedish trucks, Euro III, Euro IV, Euro V, EEV, and Euro VI HDTs accounted for $3 \%$, $5 \%, 30 \%, 5 \%$, and $57 \%$, respectively (Fig. S5).

\subsection{Emissions variability}

Differences in operating and ambient conditions may lead to differences in pollutant emission factors for the same HDT. In this study, we utilized measurement data from 55 HDTs which passed the sampling location repeatedly, yielding a total of 137 plumes. The average pollutant emission factors of each HDT plotted against the individual plume measurements of the corresponding HDT are shown in Fig. S6. In general, the emission factors of PM, non-volatile PN, and $\mathrm{NO}_{x}$ showed little variation $\left(R^{2} \geq 0.77\right)$ among multiple passages of the same HDT; however, higher variability was observed in the PN emissions. This is likely related to variations in the formation of nucleation mode particles from volatile compounds, which are more sensitive to driving (Zheng et al., 2014) and dilution conditions. In the following discussion, for HDTs with multiple passages, the average pollutant emission factors of all the detected plumes were used for that individual HDT.

\subsection{Emissions factors (EFs) of particles and gaseous pollutants}

Figure $2 \mathrm{a}$ and $\mathrm{b}$ show the box-and-whisker plots of PM and PN emission factors (EFs) for different Euro classes. Generally, both PM and PN emissions decreased with more stringent Euro emission standards, and especially for Euro VI where larger changes in emission characteristics were evident. These decreasing trends are statistically significant at the $95 \%$ confidence interval (CI) using the JonckheereTerpstra test, a non-parametric test for trends in ordered groups. In addition to $\mathrm{PM}$ and $\mathrm{PN}$, the emission trends of $\mathrm{BC}, \mathrm{NO}_{x}, \mathrm{CO}$, and $\mathrm{HC}$ with respect to the level of stringency of Euro standards were statistically examined. Using Euro III HDTs (median $\mathrm{EF}_{\mathrm{PM}}=586 \mathrm{mg}(\mathrm{kg} \text { fuel) })^{-1}$ ) as a baseline, the median EFPM for Euro IV, Euro V, EEV, and Euro VI HDTs have been reduced by $78.1 \%, 86.1 \%, 88.9 \%$, and $99.8 \%$, respectively. In particular, Euro VI HDTs have a median $\mathrm{EF}_{\mathrm{PM}}$ of only $1.4 \mathrm{mg}(\mathrm{kg} \text { fuel })^{-1}$ (Fig. 2a). While it is noted that Euro III to Euro VI standard certifications are based on chassis dynamometer cycle measurements, the Euro VI regulations have started to include additional off-cycle and in-service conformity testing. The Euro emission standard of transient testing for heavy-duty engines gives emission limits as brake-specific emission factors, as mass ( $\mathrm{g}$ ) of a specific pollutant or number (particles) per kilowatt-hour $(\mathrm{kWh})$. In order to enable a comparison with the Euro emission standard, the EFs in grams (or particles) per kilograms fuel were converted using a brake-specific fuel consumption (BSFC) of $231.5 \mathrm{~g} \mathrm{kWh}^{-1}$. This is the average value for the long-haul and regional delivery cycles of chassis dynamometer tests of a typical Euro VI truck (Rexeis et al., 2018). The uncertainty of the BSFC for different Euro class HDTs operating over a wide range of engine conditions is generally within $25 \%$ (Mahmoudzadeh Andwari et al., 2017; He et al., 2017; Dreher and Harley, 1998; Heywood, 1988). Note that our measurements represent points of time similar to those in a cycle where the particle emissions can be most prominent. Looking at a whole cycle, this value will be averaged; hence, the results from our instantaneous plume measurements may represent an upper limit of the emissions. In Fig. 2a, the right $y$ axis gives the EFs converted into units of $\mathrm{g} \mathrm{kWh}^{-1}$ and the Euro standards are shown as blue crosses.

In general, the measured median $\mathrm{EF}_{\mathrm{PM}}$ values are lower than the Euro standards for all HDT types. In particular, the median $\mathrm{EF}_{\mathrm{PM}}$ for Euro VI HDTs is more than 1 order of magnitude lower than the Euro standard regulation value since diesel particulate filters (DPFs) are required for these Euro 

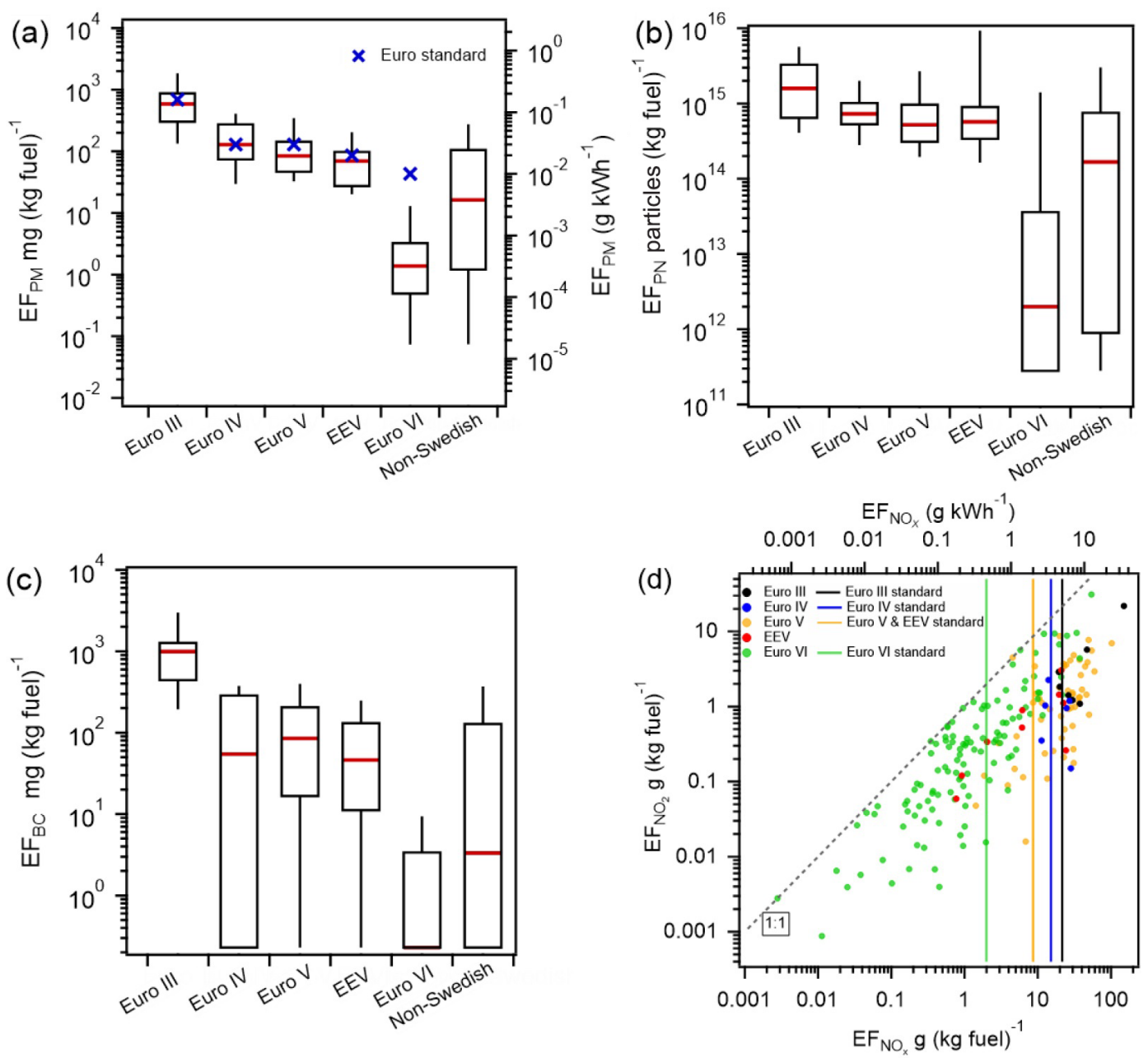

Figure 2. (a) $\mathrm{EF}_{\mathrm{PM}}$, (b) $\mathrm{EF}_{\mathrm{PN}}$, (c) $\mathrm{EF}_{\mathrm{BC}}$, (d) $\mathrm{EF}_{\mathrm{NO}_{2}}$ and $\mathrm{EF}_{\mathrm{NO}_{x}}$ for Euro III to Euro VI and non-Swedish HDTs. Non-detectable pollutant emission signals for captured plumes have been replaced by $\mathrm{EF}_{\min }$. For box-and-whisker plots, the top and the bottom line of the box are 75th and 25th percentiles of the data, the red line inside the box is the median, and the top and bottom whiskers are 90th and 10th percentiles. Note that the median $\mathrm{EF}_{\mathrm{BC}}$ of Euro VI HDTs overlaps with the bottom of the box. $\mathrm{EF}_{\mathrm{NO}_{x}}$ values in (d) are in $\mathrm{NO}_{2}$ equivalents. HDTs with either $\mathrm{EF}_{\mathrm{NO}_{2}}$ or $\mathrm{EF}_{\mathrm{NO}_{x}}$ lower than the detection limits of the instruments were removed in (d) for illustration purposes. Note that the comparison with the emission standard is only indicative as they are based on test cycle performance.

VI HDTs to comply with PM and PN standards (Williams and Minjares, 2016). No information about potential retrofits of tested HDTs was available for the vehicles measured in this study. The effectiveness of DPFs in reducing particle emissions has been confirmed by various studies (Martinet et al., 2017; May et al., 2014; Mendoza-Villafuerte et al., 2017; Moody and Tate, 2017; Preble et al., 2015). For example, Bergmann et al. (2009) illustrated that post-DPF PM concentrations decreased by $99.5 \%$ compared with pre-DPF for the New European Driving Cycle (NEDC). In real-world measurements, at least $\sim 90 \%$ reductions in PM emissions compared to typical pre-DPF levels have been reported (Bishop et al., 2015). Euro emission standards for PM of Euro IV and Euro $V$ heavy-duty diesel engines are the same, while the measured median $\mathrm{EF}_{\mathrm{PM}}$ of the Euro $\mathrm{V}$ fleet was around
1.5 times lower than that of the Euro IV fleet. The control of diesel engine emissions typically requires a compromise between $\mathrm{NO}_{x}$ and particle emission reduction (Clark et al., 1999). The $\mathrm{NO}_{x}$ emission standard is more stringent for Euro V compared to Euro IV (a factor of $43 \%$ lower), and hence Euro V HDTs are generally equipped with SCR or EGR to reduce $\mathrm{NO}_{x}$. In contrast, Euro IV engines are rarely equipped with $\mathrm{NO}_{x}$ after-treatment systems, and thus they must achieve the $\mathrm{NO}_{x}$ emission limits by tuning the engine performance parameters at the expense of higher PM emissions (Preble et al., 2018; Van Setten et al., 2001). In each of the Euro III, Euro IV, Euro V, and EEV classes, $25 \%-50 \%$ of all the measured HDTs had an EFPM higher than their corresponding Euro standards. As described previously, this comparison with the Euro standard is relative and indicative. The 
higher emissions from individual HDTs may indicate deterioration of engine performance due to wear caused by ageing, mileage accumulation, or inadequate maintenance. Our study shows that Euro VI HDTs generally have low PM emissions, but HDTs from older Euro classes frequently exceeded their PM emission limits, suggesting that improved maintenance and suitable retrofitting of older engines are needed.

For PN emissions, $\mathrm{EF}_{\mathrm{PN}}$ shows an overall trend similar to EFPM. However, a large data scatter was evident for Euro VI HDTs, likely due to the sensitivity of nucleation mode particle formation to changes in driving conditions (Fig. 2b). Zheng et al. (2014) reported high concentrations of nucleation mode particles under uphill driving conditions but low concentrations under cruise and downhill driving conditions. It is important to note that the median EFPN $_{\mathrm{PN}}$ Euro VI HDTs was significantly lower than those from the other Euro type HDTs, which indicates efficient PM removal by the DPF without compromising on total PN emission. Nonetheless, the decrease in particle number in the accumulation mode removes particle surface area available for condensation, and therefore it favours nucleation of organics from fuel and lubrication oil. Le Breton et al. (2019) confirmed the contribution of lubrication oil in bus emissions. Besides, DPFs can act as a sulfur reservoir, and, when excess sulfur is released, $\mathrm{SO}_{2}$-to- $\mathrm{SO}_{3}$ conversion can take place once the aftertreatment temperature reaches a critical level (Herner et al., 2011). In this case, total particle number emissions can increase due to nucleation from gas-phase sulfuric acid. Since the fuel sulfur content is low, more than $90 \%$ of Euro VI HDTs had an $\mathrm{EF}_{\mathrm{SO}_{2}}$ value lower than the threshold; in this study, organics would play a more important role in the formation of nucleation mode particles.

Figure 2c shows that the median $\mathrm{EF}_{\mathrm{BC}}$ was reduced by more than $99 \%$ for Euro VI HDTs compared to Euro III HDTs, and the median $\mathrm{EF}_{\mathrm{BC}}$ of Euro VI HDTs was even at the threshold $\left(0.2 \mathrm{mg}(\mathrm{kg} \text { fuel })^{-1}\right)$. The BC emissions generally showed a decrease from Euro III to Euro VI HDTs (Jonckheere-Terpstra test, $p<0.01$ ), which is similar to the

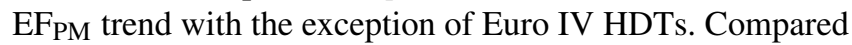
with Euro V HDTs, the median $\mathrm{EF}_{\mathrm{BC}}$ of Euro IV HDTs is $35 \%$ lower; however, the emission of the mixture of $\mathrm{BC}$ and BrC from Euro IV HDTs is higher (Fig. S7a). Euro IV HDTs had the highest BrC contribution to the total lightabsorbing substances among all the Euro classes (Fig. S7b).

Figure $2 \mathrm{~d}$ compares the emissions of $\mathrm{NO}_{2}$ and $\mathrm{NO}_{x}$ from different Euro class HDTs. The vertical lines represent the different Euro standards. HDTs with either $\mathrm{EF}_{\mathrm{NO}_{2}}$ or $\mathrm{EF}_{\mathrm{NO}_{x}}$ values lower than the detection limits of the instruments were removed in Fig. 2d for illustration purposes, while all the presented statistical analyses include all the data as outlined above. In general, Euro VI HDTs exhibit a more than $90 \%$ reduction in both median and average $\mathrm{EF}_{\mathrm{NO}_{x}}$ compared to Euro III HDTs. This is consistent with Carslaw et al. (2011), who estimated a $93 \% \mathrm{NO}_{x}$ reduction from Euro III to Euro VI for heavy goods vehicles (HGVs) in the United Kingdom.
Relatively, the Euro V HDTs had a larger fraction exceeding their Euro standard, which may be due to the combined effects of poor engine tuning and the inactivity (low temperature) or deterioration of SCR systems. Newer engines tend to exhibit a higher $\mathrm{NO}_{2}$ emission fraction at a similar $\mathrm{NO}_{x}$ level, and the Euro VI HDTs show a relatively low median $\mathrm{EF}_{\mathrm{NO}_{2}}$ with a large range of data scatter and several high emitters. A continuous increase in $\mathrm{EF}_{\mathrm{NO}_{2}} / \mathrm{EF}_{\mathrm{NO}_{x}}$ was evident from Euro IV to Euro VI HDTs (Fig. S8b). This trend is consistent with Kozawa et al. (2014), who reported an increase in the share of $\mathrm{NO}_{2}$ to total $\mathrm{NO}_{x}$ from Euro III to Euro $\mathrm{V}$ vehicles. Euro VI HDTs have a higher $\mathrm{NO}_{2}$ fraction, because the DOC upstream of the filter is used to convert NO to $\mathrm{NO}_{2}$ to control the soot loading in the DPF and facilitate the passive regeneration (Van Setten et al., 2001). A failure of the $\mathrm{NO}_{2}$ reduction due to the inactivity of the SCR, resulting from low exhaust gas temperature, may yield a higher $\mathrm{NO}_{2}$ emission (Bishop et al., 2010; Heeb et al., 2010; Herner et al., 2009; May et al., 2014; Thiruvengadam et al., 2015). A more significant decrease in $\mathrm{NO}_{x}$ than $\mathrm{NO}_{2}$ emissions of Euro VI HDTs may cause an increase in $\mathrm{EF}_{\mathrm{NO}_{2}} / \mathrm{EF}_{\mathrm{NO}_{x}}$.

Table 1 compares the average emission data of $\mathrm{PM}$ and PN of the current work with previous studies according to the HDT type and gives information on measurement methods used and driving conditions. Generally, the EFPM and $\mathrm{EF}_{\mathrm{PN}}$ in this study are within the reported ranges of HDV emissions in the literature. Our estimated EFPM values of Euro III HDTs are comparable to those of Euro III buses in Hallquist et al. (2013) and Pirjola et al. (2016). HDTs and buses within the same Euro class emit similar amounts of PM. Watne et al. (2018) show that DPF-retrofitted Euro III buses have much lower particle EFs. While EF PM $_{\text {is highly }}$ dependent on driving conditions such as speed and acceleration, the average EFPM of Euro IV, Euro V, and EEV HDTs of this study $\left(172,146\right.$, and $78 \mathrm{mg}(\mathrm{kg} \text { fuel })^{-1}$, respectively) are comparable to previous studies (Hallquist et al., 2013; Pirjola et al., 2016; Watne et al., 2018). The average EFPM of Euro VI HDTs $\left(5 \mathrm{mg}(\mathrm{kg} \text { fuel })^{-1} / 1.1 \mathrm{mg} \mathrm{km}^{-1}\right)$ is within the range of emissions from HDVs with DPFs, e.g. 0.6-20.5 $\mathrm{mg} \mathrm{km}^{-1}$, for a recent chassis dynamometer test (Jiang et al., 2018) and $2.5-8.7 \mathrm{mg} \mathrm{km}^{-1}$ for road measurements in California (Quiros et al., 2016). Note that size ranges and measurement methodologies may differ among the studies as listed in Table 1 . Since most of the particle emissions related to road traffic combustion are below $560 \mathrm{~nm}$ (Fig. 4), the size range in our study is comparable to most other wider-range PM measurements. Larger particles from road measurements of total PM may include non-combustion-related particles, e.g. resuspended road dust, tire particles, and brake-wear particles, and they should be interpreted with caution. In contrast to $\mathrm{EF}_{\mathrm{PM}}$, a much less obvious decrease in average $\mathrm{EF}_{\mathrm{PN}}$ was observed across different Euro classes. The reason for the high average particle emission for EEV and Euro VI is likely due to high emissions of nucleation mode particles from a number of HDTs. 
Table 1. Comparison of the average emission data ${ }^{\mathrm{a}}$ for PM and PN from the present study with literature data. Bold font was used for better illustration of different Euro classes.

\begin{tabular}{|c|c|c|c|c|c|c|}
\hline Vehicle type & $\begin{array}{c}\text { Speed } \\
\mathrm{km} \mathrm{h}^{-1}\end{array}$ & $\underset{\mathrm{nm}}{D_{\mathrm{p}} \text { range }}$ & Method & Instrument & $\begin{array}{c}\mathrm{EFPM}_{\mathrm{PM}} \\
\mathrm{mg}(\mathrm{kg} \text { fuel })^{-1}\end{array}$ & $\begin{array}{c}\mathrm{EF} \\
10^{14} \text { particles } \\
(\mathrm{kg} \text { fuel })^{-1}\end{array}$ \\
\hline Euro III HDT in this study & $26 \pm 6^{b}$ & $5.6-560$ & roadside & EEPS & $684 \pm 365$ & $20.3 \pm 11.7$ \\
\hline \multirow{2}{*}{$\begin{array}{l}\text { Euro III bus } \\
\text { (Hallquist et al., 2013) }\end{array}$} & acceleration & $5.6-560$ & roadside & EEPS & $6.7-2074$ & $0.11-45$ \\
\hline & constant speed & $5.6-560$ & roadside & EEPS & $151-273$ & $0.12-4.2$ \\
\hline \multirow{2}{*}{$\begin{array}{l}\text { Euro III bus with DPF } \\
\text { (Hallquist et al., 2013) }\end{array}$} & acceleration & $5.6-560$ & roadside & EEPS & $62-2465$ & $1.9-23$ \\
\hline & constant speed & $5.6-560$ & roadside & EEPS & $41-142$ & $1.1-9.7$ \\
\hline \multirow[t]{2}{*}{$\begin{array}{l}\text { Euro III bus } \\
\text { (Pirjola et al., 2016) }\end{array}$} & $\begin{array}{c}\leq 25 \\
\text { (bus depot) }\end{array}$ & $\begin{array}{c}\mathrm{PM}_{1} \\
D_{\mathrm{p}} \geq 2.5\end{array}$ & plume chasing & $\begin{array}{l}\mathrm{ELPI}^{\mathrm{c}} \\
\mathrm{CPC}\end{array}$ & $1240 \pm 220^{b}$ & $20.6 \pm 3.2^{b}$ \\
\hline & $\begin{array}{c}\leq 45 \\
\text { (bus line) }\end{array}$ & $\begin{array}{c}\mathrm{PM}_{1} \\
D_{\mathrm{p}} \geq 2.5\end{array}$ & plume chasing & $\begin{array}{l}\mathrm{ELPI}^{\mathrm{c}} \\
\mathrm{CPC}\end{array}$ & 500 & 17.7 \\
\hline $\begin{array}{l}\text { Euro III bus with DPF + SCR } \\
\text { (Watne et al., 2018) }\end{array}$ & acceleration & $5.6-560$ & roadside & EEPS & $8.9 \pm 0.2$ & $0.12 \pm 0.12$ \\
\hline $\begin{array}{l}\text { Euro III bus with DPF + SCR } \\
\text { (Liu et al., 2019) }\end{array}$ & $\begin{array}{l}\text { stop and go } \\
\text { (bus stop) }\end{array}$ & $5.6-560$ & roadside & EEPS & $30 \pm 26^{\mathrm{b}}$ & $14.0 \pm 3.0^{\mathrm{b}}$ \\
\hline $\begin{array}{l}\text { Euro III diesel bus and truck } \\
\text { (Zavala et al., 2017) }\end{array}$ & driving cycle & $35-1000$ & $\begin{array}{l}\text { plume chasing } \\
\text { and roadside }\end{array}$ & SP-AMS $^{f}$ & 4300 & - \\
\hline Euro IV HDT in this study & $23 \pm 8^{b}$ & $5.6-560$ & roadside & EEPS & $172 \pm 68$ & $8.7 \pm 3.0$ \\
\hline Euro IV bus with EGR & acceleration & $5.6-560$ & roadside & EEPS & $562-3089$ & $13-44$ \\
\hline (Hallquist et al., 2013) & constant speed & $5.6-560$ & roadside & EEPS & $91-489$ & $5.8-47$ \\
\hline \multirow{2}{*}{$\begin{array}{l}\text { Euro IV bus with EGR + DPF } \\
\text { (Hallquist et al., 2013) }\end{array}$} & acceleration & $5.6-560$ & roadside & EEPS & $177-650$ & $5.1-13$ \\
\hline & constant speed & $5.6-560$ & roadside & EEPS & $58-61$ & $2.6-3.1$ \\
\hline $\begin{array}{l}\text { Euro IV bus with EGR + DPF } \\
\text { (Pirjola et al., 2016) }\end{array}$ & $\begin{array}{c}\leq 25 \\
\text { (bus depot) }\end{array}$ & $\begin{array}{c}\mathrm{PM}_{1} \\
D_{\mathrm{p}} \geq 2.5\end{array}$ & plume chasing & $\begin{array}{c}\mathrm{ELPI}^{\mathrm{c}} \\
\mathrm{CPC}\end{array}$ & $1190 \pm 520^{b}$ & $8.9 \pm 1.6^{\mathrm{b}}$ \\
\hline $\begin{array}{l}\text { Euro IV bus with SCR } \\
\text { (Watne et al., 2018) }\end{array}$ & acceleration & $5.6-560$ & roadside & EEPS & $145-560$ & $3-13$ \\
\hline $\begin{array}{l}\text { Euro IV diesel bus and truck } \\
\text { (Zavala et al., 2017) }\end{array}$ & driving cycle & $35-1000$ & $\begin{array}{l}\text { plume chasing } \\
\text { and roadside }\end{array}$ & SP-AMS $^{f}$ & 1800 & - \\
\hline Euro V HDT in this study & $27 \pm 7^{b}$ & $5.6-560$ & roadside & EEPS & $146 \pm 49$ & $9.7 \pm 2.7$ \\
\hline \multirow{2}{*}{$\begin{array}{l}\text { Euro V bus + SCR } \\
\text { (Hallquist et al., 2013) }\end{array}$} & acceleration & $5.6-560$ & roadside & EEPS & $125-766$ & $4.4-92$ \\
\hline & constant speed & $5.6-560$ & roadside & EEPS & $41-509$ & $2.7-33$ \\
\hline Euro V bus (Watne et al., 2018) & acceleration & $5.6-560$ & roadside & EEPS & $145 \pm 70$ & $3.0 \pm 1.7$ \\
\hline $\begin{array}{l}\text { Euro V HDV with SCR } \\
\text { (Rymaniak et al., 2017) }\end{array}$ & average at 45 & $\begin{array}{c}\mathrm{PM} / \\
5.6-560\end{array}$ & PEMS & $\begin{array}{l}\text { MSS } \\
\text { EEPS }\end{array}$ & $1840^{\mathrm{d}}$ & $0.09^{\mathrm{d}}$ \\
\hline $\begin{array}{l}\text { Euro V bus with SCR } \\
\text { (Liu et al., 2019) }\end{array}$ & $\begin{array}{l}\text { stop and go } \\
\text { (bus stop) }\end{array}$ & $5.6-560$ & roadside & EEPS & $180 \pm 15^{b}$ & $6.5 \pm 2.9^{b}$ \\
\hline $\begin{array}{l}\text { Euro V diesel bus and truck } \\
\text { (Zavala et al., 2017) }\end{array}$ & driving cycle & $35-1000$ & $\begin{array}{l}\text { plume chasing } \\
\text { and roadside }\end{array}$ & SP-AMS & 720 & - \\
\hline EEV HDT in this study & $25 \pm 8^{\mathrm{b}}$ & $5.6-560$ & roadside & EEPS & $78 \pm 35$ & $16.5 \pm 23.6$ \\
\hline $\begin{array}{l}\text { EEV bus with EGR + DPF } \\
\text { (Pirjola et al., 2016) }\end{array}$ & $\begin{array}{c}\leq 25 \\
\text { (bus depot) }\end{array}$ & $\begin{array}{c}\mathrm{PM}_{1} / \\
D_{\mathrm{p}} \geq 2.5\end{array}$ & plume chasing & $\begin{array}{l}\mathrm{ELPI}^{\mathrm{c}} \\
\mathrm{CPC}\end{array}$ & $400 \pm 280^{b}$ & $2.1 \pm 0.1^{b}$ \\
\hline $\begin{array}{l}\text { EEV bus with SCR } \\
\text { (Pirjola et al., 2016) }\end{array}$ & $\begin{array}{c}\leq 25 \\
\text { (bus depot) }\end{array}$ & $\begin{array}{c}\mathrm{PM}_{1} / \\
D_{\mathrm{p}} \geq 2.5\end{array}$ & plume chasing & $\begin{array}{c}\text { ELPI }^{c} \\
\text { CPC }\end{array}$ & $280 \pm 170^{b}$ & $7.0 \pm 3.8^{\mathrm{b}}$ \\
\hline
\end{tabular}


Table 1. Continued.

\begin{tabular}{|c|c|c|c|c|c|c|}
\hline Vehicle type & $\begin{array}{c}\text { Speed } \\
\mathrm{km} \mathrm{h}^{-1}\end{array}$ & $\begin{array}{l}D_{\mathrm{p}} \text { range } \\
\mathrm{nm}\end{array}$ & Method & Instrument & $\begin{array}{c}\mathrm{EF}_{\mathrm{PM}} \\
\mathrm{mg}(\mathrm{kg} \text { fuel })^{-1}\end{array}$ & $\begin{array}{c}\mathrm{EF} \\
10^{14} \text { particles } \\
(\mathrm{kg} \text { fuel })^{-1}\end{array}$ \\
\hline $\begin{array}{l}\text { EEV with DOC + DPF + SCR } \\
\text { (Rymaniak et al., 2017) }\end{array}$ & average at 45 & $\begin{array}{c}\mathrm{PM} / \\
5.6-560\end{array}$ & PEMS & $\begin{array}{l}\text { MSS } \\
\text { EEPS }\end{array}$ & $236^{\mathrm{d}}$ & $0.02^{\mathrm{d}}$ \\
\hline $\begin{array}{l}\text { EEV bus } \\
\text { (Jarvinen et al., 2019) }\end{array}$ & stop and go & $\begin{array}{l}\mathrm{PM}_{1} / \\
D_{\mathrm{p}} \geq 3\end{array}$ & plume chasing & $\begin{array}{l}\mathrm{ELPI}^{\mathrm{c}} \\
\mathrm{CPC}\end{array}$ & 200 & 8.6 \\
\hline Euro VI HDT in this study & $29 \pm 8^{b}$ & $5.6-560$ & roadside & EEPS & $5 \pm 2$ & $8.5 \pm 4.6$ \\
\hline $\begin{array}{l}\text { Euro VI bus } \\
\text { (Jarvinen et al., 2019) }\end{array}$ & stop and go & $\begin{array}{c}\mathrm{PM}_{1} / \\
D_{\mathrm{p}} \geq 3\end{array}$ & plume chasing & $\begin{array}{l}\text { ELPI }^{\mathrm{c}} \\
\mathrm{CPC}\end{array}$ & 70 & 5 \\
\hline $\begin{array}{l}\text { Euro VI HDV } \\
\text { (Moody and Tate, 2017) }\end{array}$ & $13-86$ & - & PEMS & - & $28-33^{\mathrm{d}}$ & - \\
\hline $\begin{array}{l}\text { Euro VI HDT } \\
\text { (Grigoratos et al., 2019) }\end{array}$ & $65-74$ & - & PEMS & - & - & $0.002-0.01^{\mathrm{d}}$ \\
\hline $\begin{array}{l}\text { HDT without available Euro } \\
\text { type information }\end{array}$ & $27 \pm 7^{b}$ & $5.6-560$ & roadside & EEPS & $47 \pm 23$ & $7.5 \pm 7.3$ \\
\hline Total Swedish HDT & $28 \pm 7^{b}$ & $5.6-560$ & roadside & EEPS & $96 \pm 36$ & $9.6 \pm 2.7$ \\
\hline Total non-Swedish HDT & $26 \pm 8^{b}$ & $5.6-560$ & roadside & EEPS & $117 \pm 42$ & $11.1 \pm 4.2$ \\
\hline \multicolumn{7}{|l|}{$\begin{array}{l}\text { Non-European HDV with } \\
\text { different ATSs }\end{array}$} \\
\hline $\begin{array}{l}\text { HDV with DPF } \\
\text { (Wang et al., 2017; } \\
\text { Quiros et al., 2016) }\end{array}$ & $13-80$ & $\begin{array}{c}\mathrm{PM} \\
D_{\mathrm{p}} \geq 5\end{array}$ & PEMS & $\begin{array}{l}\text { gravimetric } \\
\mathrm{CPC}\end{array}$ & $12-41^{\mathrm{d}}$ & $0.006-13.2$ \\
\hline $\begin{array}{l}\text { Heavy-duty HDV } \\
\text { with DPF + SCR } \\
\text { (Thiruvengadam et al., 2015) }\end{array}$ & driving cycle & $\mathrm{PM}$ & $\begin{array}{c}\text { chassis } \\
\text { dynamometer }\end{array}$ & gravimetric & $6-29^{d}$ & - \\
\hline $\begin{array}{l}\text { HDV with DPF }+ \text { SCR } \\
\text { (Jiang et al., 2018) }\end{array}$ & driving cycle & $\mathrm{PM}_{2.5}$ & $\begin{array}{c}\text { chassis } \\
\text { dynamometer }\end{array}$ & gravimetric & $3-97^{\mathrm{d}}$ & - \\
\hline $\begin{array}{l}\text { HDT (model year 2004-2006) } \\
\text { (Preble et al., 2015) }\end{array}$ & $\begin{array}{l}\text { accelerating or } \\
\text { cruise at } 48\end{array}$ & $D_{\mathrm{p}} \geq 2.5$ & roadside & $\mathrm{CPC}$ & - & $47.2 \pm 9.7$ \\
\hline $\begin{array}{l}\text { HDT with SCR + DPF } \\
\text { (model year 2010-2013) } \\
\text { (Preble et al., 2015) }\end{array}$ & & $D_{\mathrm{p}} \geq 2.5$ & roadside & $\mathrm{CPC}$ & - & $15.9 \pm 11.5$ \\
\hline $\begin{array}{l}\text { HDV (mean model year 2005) } \\
\text { (Bishop et al., 2015) }\end{array}$ & $15.7-16.8$ & $\mathrm{PM}_{1.2}$ & OHMS $^{\mathrm{g}}$ & $\begin{array}{l}\text { digital mass } \\
\text { monitor }\end{array}$ & 650 & - \\
\hline $\begin{array}{l}\text { HDV (mean model year 2009) } \\
\text { (Bishop et al., 2015) }\end{array}$ & $7.7-9.3$ & $\mathrm{PM}_{1.2}$ & OHMS $^{g}$ & $\begin{array}{l}\text { digital mass } \\
\text { monitor }\end{array}$ & 31 & - \\
\hline $\begin{array}{l}\text { HDV without after treatment } \\
\text { (Quiros et al., 2018) }\end{array}$ & driving cycle & $\mathrm{PM}_{2.5}$ & $\begin{array}{c}\text { chassis } \\
\text { dynamometer }\end{array}$ & gravimetric & $1980^{\mathrm{d}}$ & - \\
\hline $\begin{array}{l}\text { HDV + DPF } \\
\text { (Quiros et al., 2018) }\end{array}$ & driving cycle & $\mathrm{PM}_{2.5}$ & $\begin{array}{c}\text { chassis } \\
\text { dynamometer }\end{array}$ & gravimetric & $6-9^{d}$ & - \\
\hline
\end{tabular}

${ }^{a}$ Given errors are at $95 \%$ CI. ${ }^{b}$ Standard deviation. ${ }^{c}$ ELPI, electrical low-pressure impactor. ${ }^{\mathrm{d}}$ Average fuel consumption of $0.26 \mathrm{~L} \mathrm{~km}^{-1}$ for HDV during long-haul and regional delivery tests (Rexeis et al., 2018); the density of $0.815 \mathrm{~kg} \mathrm{dm}^{-3}$ (Hallquist et al., 2013) for diesel particles was assumed for unit conversion. ${ }^{\mathrm{e}}$ MSS, micro soot sensor. ${ }^{\mathrm{f}}$ SP-AMS, soot particle aerosol mass spectrometer. ${ }^{\mathrm{g}}$ OHMS, on-road heavy-duty vehicle emissions monitoring system. 


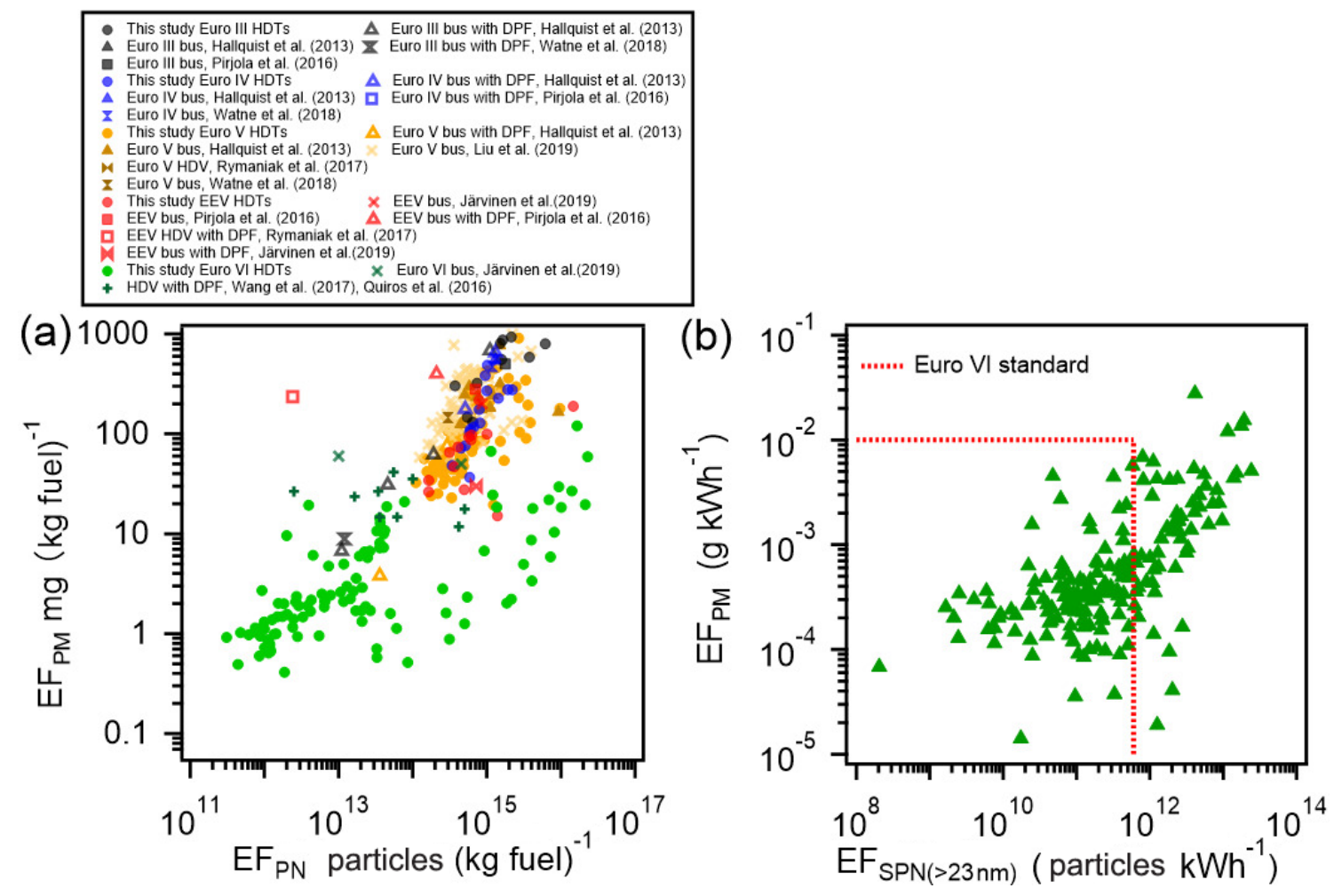

Figure 3. (a) $\mathrm{EF}_{\mathrm{PM}}$ and $\mathrm{EF}_{\mathrm{PN}}$ of individual HDTs in this study and previous studies and (b) the relationship between $\mathrm{EF}_{\mathrm{PM}}$ and $\mathrm{EF}_{\mathrm{SPN}}$ of Euro VI HDTs. Dashed red lines represent Euro emission standards (horizontal: PM emission standard; vertical: SPN emission standard). HDTs with either $\mathrm{EF}_{\mathrm{PM}}$ or $\mathrm{EF}_{\mathrm{PN}}$ values lower than the detection limits of the instruments were removed in (a) for illustration purposes. Note that the comparison with the emission standard is only indicative as they are based on test cycle performance.

In Fig. 3a, EFPM and $\mathrm{EF}_{\mathrm{PN}}$ of individual HDTs in this study and selected previous studies are plotted. HDTs with either $\mathrm{EF}_{\mathrm{PM}}$ or $\mathrm{EF}_{\mathrm{PN}}$ lower than $0.07 \mathrm{mg}(\mathrm{kg} \text { fuel })^{-1}$ or $2.8 \times$ $10^{11}$ particles $(\mathrm{kg} \text { fuel })^{-1}$, respectively, were removed from the figure ( $24 \%$ of the data) for illustration purposes. Their corresponding measurements were below the detection limits of the instruments, while the presented statistical analyses include all the data as outlined above. Generally, both $\mathrm{EF}_{\mathrm{PM}}$ and $\mathrm{EF}_{\mathrm{PN}}$ exhibited a decreasing trend from Euro III to Euro IV and from Euro V to EEV HDTs (JonckheereTerpstra test, $p<0.01)$. Overall, Euro VI HDTs had drastically lower PM emissions but highly scattered PN emissions. Older Euro type buses retrofitted with DPF were shown to have reduced particle emissions, and some retrofitted Euro III buses (black open triangles in Fig. 3a) may perform as well as Euro VI HDTs, indicating the effectiveness of retrofitting older HDTs.

In more recent European standards, PN regulation has been introduced. The SPN as defined by the European Particle Measurement Programme (PMP) is the number of particles which remains after passing through an evaporation tube with a wall temperature of $300-400^{\circ} \mathrm{C}$ (Zheng et al., 2011). The PMP only measures and regulates solid particles with a diameter larger than $23 \mathrm{~nm}$, because measurements of smaller particles in the nucleation mode have poor repeatability (Martini et al., 2009). SPN larger than $23 \mathrm{~nm}$ was integrated into the European emission regulation in 2013 for Euro VI heavy-duty engines (Giechaskiel et al., 2012). A potential issue of evaporation measurements is that a fraction of the less than $23 \mathrm{~nm}$ particles can also be formed downstream of the European PMP methodology through renucleation of semi-volatile precursors (Zheng et al., 2012, 2011). In our study, the TD temperature of $250^{\circ} \mathrm{C}$ is lower than the maximum temperature used by the PMP $\left(300-400^{\circ} \mathrm{C}\right)$ and does not follow the exact operation specifications of the PMP. However, Amanatidis et al. (2018) summarized that TD is a suitable alternative approach for the removal of volatile particles. Particles larger than $23 \mathrm{~nm}$ downstream of the TD were measured by the EEPS, and we integrated the size bins from 23.5 to $560 \mathrm{~nm}$ to represent the SPN. Figure $3 \mathrm{~b}$ compares the $\mathrm{EF}_{\mathrm{PM}}$ and $\mathrm{EF}_{\mathrm{SPN}}$ of Euro VI HDTs. Generally, aftertreatment control systems could not reduce SPN emissions as effectively as PM emissions, indicating that more control of SPN emission of Euro VI HDTs may be necessary.

Shown in Table 2 are the average EFs of gaseous pollutants $\left(\mathrm{NO}_{x}, \mathrm{CO}, \mathrm{HC}\right)$ in this study compared with other studies. $\mathrm{EF}_{\mathrm{NO}_{x}}$ generally decreased from the Euro III $\left(43.3 \mathrm{~g}(\mathrm{~kg} \mathrm{fuel})^{-1}\right)$ to Euro VI $\left(3.1 \mathrm{~g}(\mathrm{~kg} \text { fuel })^{-1}\right)$ class, and 
(a)

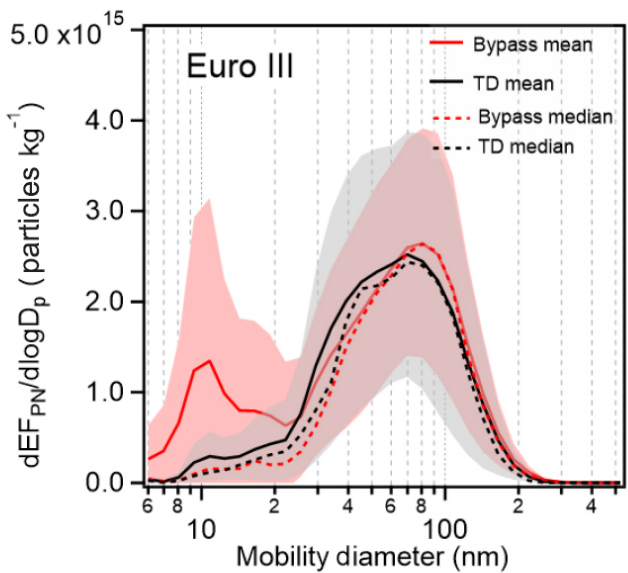

(c)

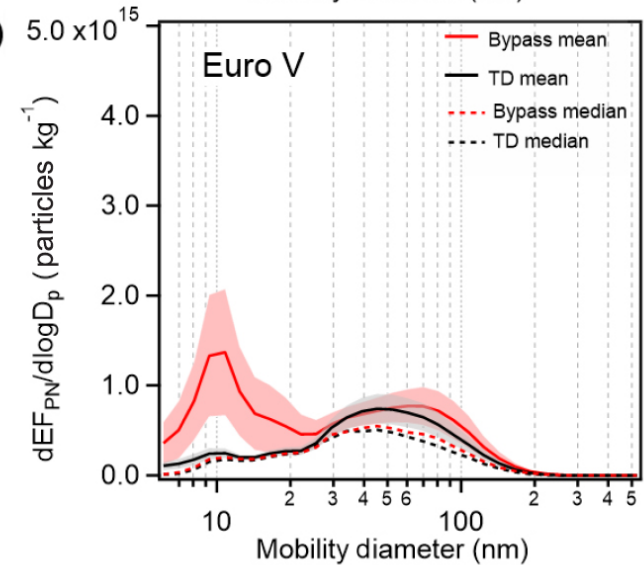

(e)

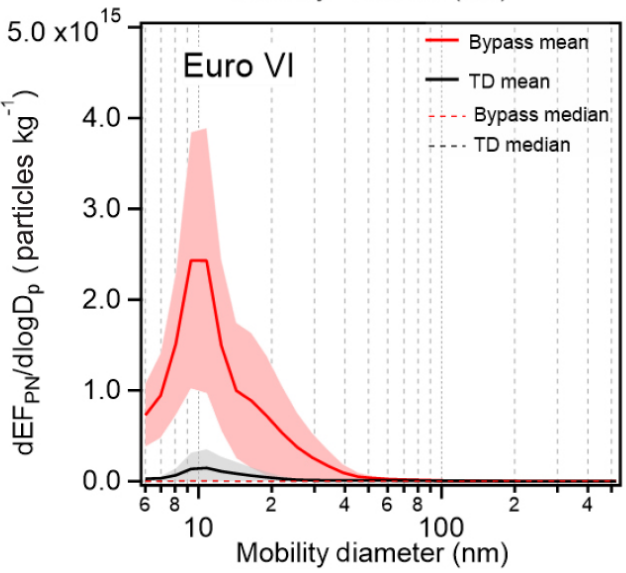

(b)
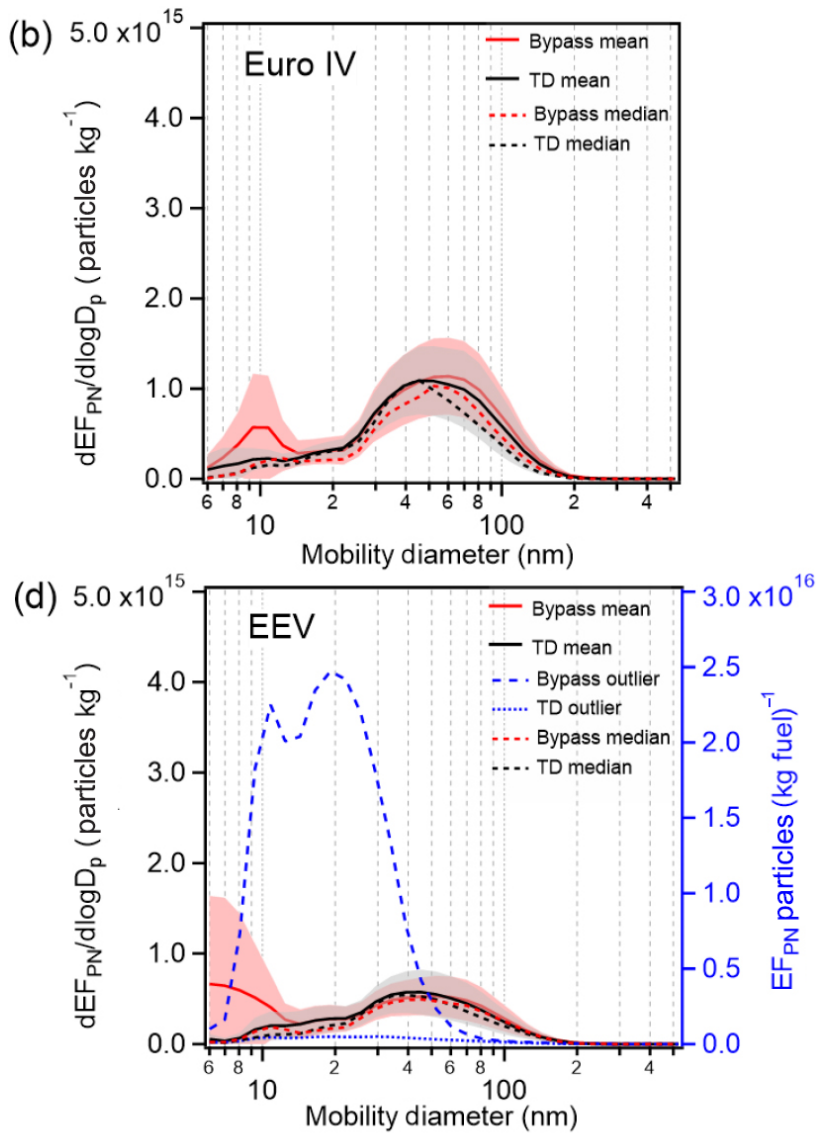

(f)

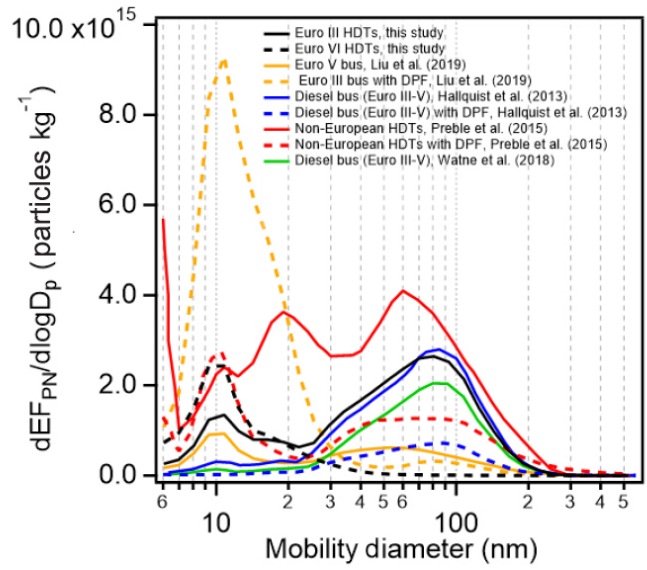

Figure 4. (a-e) Mean and median size-resolved $E F_{P N}$ and $\mathrm{EF}_{\text {non-volatile }}$ PN of different Euro class HDTs and (f) comparisons of mean sizeresolved EFPN of HDVs in this study and previous studies. Shaded regions in (a-e) represent the statistical $95 \%$ confidence interval. One HDT with extremely different EF in (d) was excluded from the analysis and shown in blue.

they are in good agreement with reported values for HDTs in the literature. The $\mathrm{EF}_{\mathrm{NO}_{x}}$ of Euro III HDTs is moderately higher in this study. Note that the $\mathrm{EF}_{\mathrm{NO}_{x}}$ and $\mathrm{EF}_{\mathrm{PM}}$ values of EEV were much higher in Pirjola et al. (2016), in which only a limited number (3-4) of vehicles were tested and hard braking was common in approaching a $90^{\circ}$ turn before accelerating again. The ratio of $\mathrm{EF}_{\mathrm{NO}_{2}}$ to $\mathrm{EF}_{\mathrm{NO}_{x}}$ generally agrees with the projection in Kousoulidou et al. (2008), on-road plume chasing measurements in Lau et al. (2015), and remote sensing studies in the UK (Carslaw and Rhys-Tyler, 2013). Carslaw et al. (2019) reported a decreasing trend of $\mathrm{EF}_{\mathrm{NO}_{2}} / \mathrm{EF}_{\mathrm{NO}_{x}}$ with vehicle mileage for Euro 6 light-duty diesel vehicles, while no significant trend was identified for Euro VI HDTs in this study. There may be other parameters influencing the $\mathrm{NO}_{x}$ emission. For example, Ko et al. (2019) reported that the $\mathrm{NO}_{x}$ emissions from Euro VI diesel vehi- 
cles were $29 \%$ higher in a traffic jam than in smooth traffic conditions. The temperature of the exhaust and DPF regeneration may also influence the $\mathrm{EF}_{\mathrm{NO}_{x}}$.

Compared with $\mathrm{EF}_{\mathrm{NO}_{x}}, \mathrm{EF}_{\mathrm{CO}}$ decreased less pronounced from Euro III to Euro VI HDTs (57\%). Compared with newer Euro class HDTs, a larger fraction of HDTs in older Euro classes have an $\mathrm{EF}_{\mathrm{CO}}$ exceeding the Euro standards, which indicates that engine deterioration may have a serious effect on the CO emissions (Fig. S8c). Hallquist et al. (2013) reported a positive relationship between $\mathrm{EF}_{\mathrm{CO}}$ and $\mathrm{EF}_{\mathrm{PM}}$, i.e. high $\mathrm{CO}$ indicates incomplete combustion which favours soot formation. DPFs may also reduce $\mathrm{CO}$ in addition to PM (Hallquist et al., 2013), which is in agreement with the lowest CO emission of $15.5 \mathrm{~g}(\mathrm{~kg} \text { fuel })^{-1}$ observed for DPF equipped Euro VI HDTs in this study. HC emission was relatively low for all HDT types, and no obvious decreasing trend was evident for $\mathrm{EF}_{\mathrm{HC}}$ from Euro III to Euro VI HDTs (Jonckheere-Terpstra test, $p=0.895$ ) (Fig. S8d and Table 2), for which the Euro VI limit is more than a factor of 3 lower than the preceding Euro V/IV standards.

The 46 Swedish HDTs without available Euro information emitted similar levels of particle and gaseous pollutants to Euro VI HDTs, and they were thus likely equipped with newer Euro class engines.

Compared with the fleet of non-Swedish HDTs, the Swedish HDT fleet generally have a lower median and average $\mathrm{EF}_{\mathrm{NO}_{x}}$, but there are no significant differences in the EF of other pollutants (Fig. 2 and Tables 1 and 2). The differences in $\mathrm{EF}_{\mathrm{NO}_{x}}$ are significant at the statistical $95 \% \mathrm{CI}$ using the Kolmogorov-Smirnov test, used in favour of the typical Student's t test to account for non-normality of the EF distributions. As information of Euro class, engine types, and treatment technologies of non-Swedish HDTs is not available, we cannot further explore why there is a difference between the two fleets.

In addition to engine Euro type, pollutant emission trends were also investigated with respect to five different vehicle manufacturers (M1, M2, M3, M4, and M5). EFPM, EF $\mathrm{PN}_{\text {, }}$ $\mathrm{EF}_{\mathrm{BC}}$, and $\mathrm{EF}_{\mathrm{NO}_{x}}$ of HDTs under the same Euro class but from different manufacturers are compared in Fig. S9. Since EF data were not normally distributed, statistical significance is assessed with a Kruskal-Wallis test. It is a non-parametric analogue of the one-way ANOVA test. The $p$ values are calculated at the statistical $95 \%$ confidence level. No significant group difference $(p>0.05)$ was observed in $\mathrm{EF}_{\mathrm{PM}}, \mathrm{EF}_{\mathrm{PN}}$, $\mathrm{EF}_{\mathrm{BC}}$, or $\mathrm{EF}_{\mathrm{NO}_{x}}$ for Euro V HDTs, i.e. HDTs (from five different manufacturers) show comparable emission characteristics. $\mathrm{EF}_{\mathrm{PM}}, \mathrm{EF}_{\mathrm{PN}}$, and $\mathrm{EF}_{\mathrm{NO}_{x}}$ of Euro VI HDTs show no dependency on manufacturers, but a significant difference was observed between M2 and M5 in $\mathrm{EF}_{\mathrm{BC}}$ of Euro VI HDTs $(p=0.016)$. (No analysis on Euro III, Euro IV, and EEV HDTs was conducted due to the limited number of vehicles from each manufacturer).

\subsection{Size-resolved $\mathbf{E F}_{\mathrm{PN}}$ of volatile and non-volatile particles}

Figure 4a-e show the average size-resolved number emission factors (solid lines) simultaneously measured via the bypass and TD lines for different Euro class HDTs. The $\mathrm{EF}_{\mathrm{PN}}$ of the volatile components is calculated as the difference of $\mathrm{EF}_{\mathrm{PN}}$ measured after the bypass line and the non-volatile component $\mathrm{EF}_{\mathrm{PN}}$ measured after the TD line. To differentiate between nucleation and accumulation mode particles, a cut-off particle diameter of $30 \mathrm{~nm}$ was used as defined by Kittelson et al. (2002). In general, all Euro III, Euro IV, Euro V, and EEV HDTs showed a bimodal particle number size distribution, with one mode peaking at $\sim 6-10 \mathrm{~nm}$ (nucleation mode) and another at $\sim 50-80 \mathrm{~nm}$ (accumulation/soot mode) (Maricq, 2007). For Euro VI HDTs, the particle number size distributions were dominated by the nucleation mode. The EFPN of the accumulation mode particles shows a decreasing trend from Euro III to EEV HDTs. The accumulation mode of the Euro VI HDTs was insignificant. For heavy-duty diesel engines without a particulate filter, nucleation mode particles are mainly formed from organics. For vehicles with DPF, both organics and the fuel sulfur content might influence the formation of nucleation mode particles (Vaaraslahti et al., 2004). Thiruvengadam et al. (2012) found a direct relationship between exhaust nanoparticles in the nucleation mode and the exhaust temperature of the DPF-SCR-equipped diesel engine. These factors lead to high variability in the nucleation mode fraction of $\mathrm{EF}_{\mathrm{PN}}$. Figure $4 \mathrm{f}$ shows that HDVs with DPF (dashed lines) exhibited lower emissions of accumulation mode particles, with no significant reduction in nucleation mode particles when compared to HDVs without DPF (solid lines). In general, the absence of significant accumulation mode particles from Euro VI HDTs was consistent with observations made from DPF-equipped HDVs. High emissions of accumulation mode particles from Euro III HDTs were consistent with measurements from HDVs without DPF in previous studies (Liu et al., 2019; Hallquist et al., 2013; Preble et al., 2015).

Most particles in the nucleation mode evaporate after passing through the TD. Sakurai et al. (2003b) reported that volatile compounds in diesel particles are mainly comprised of unburned lubrication oil. The non-volatile components in the nucleation mode may consist of metallic ash, from lubrication oil or fuel additives (Sakurai et al., 2003a), or some organic compounds of extremely low volatility (Gkatzelis et al., 2016). In the accumulation mode, the particle mode diameter shifted towards lower sizes after passing the TD. In Fig. 4a-e, we also present the median size distribution (dashed lines). There is a small difference between mean and median size distributions in the accumulation mode, while a bigger difference occurs in the nucleation mode. The latter mode is more dynamic, and there are larger possibilities for extreme values skewing the averages. 
Table 2. Comparison of the average emission data $\mathrm{a}^{\mathrm{a}}$ for $\mathrm{NO}_{x}, \mathrm{NO}_{2} / \mathrm{NO}_{x}, \mathrm{CO}$, and $\mathrm{HC}$ from the present study with literature data. Bold font was used for better illustration of different Euro classes.

\begin{tabular}{|c|c|c|c|c|c|c|}
\hline Vehicle type & $\begin{array}{c}\text { Speed } \\
\mathrm{km} \mathrm{h}^{-1}\end{array}$ & Method & $\begin{array}{c}\mathrm{EF}_{\mathrm{NO}_{x}}{ }^{\mathrm{b}} \\
\mathrm{g}(\mathrm{kg} \text { fuel })^{-1}\end{array}$ & $\begin{array}{c}\mathrm{EF}_{\mathrm{NO}_{2}} / \mathrm{EF}_{\mathrm{NO}_{x}}{ }^{\mathrm{b}} \\
\text { mass ratio } \\
\%\end{array}$ & $\begin{array}{c}\mathrm{EF}_{\mathrm{CO}}{ }^{\mathrm{c}} \\
\mathrm{g}(\mathrm{kg} \text { fuel })^{-1}\end{array}$ & $\begin{array}{c}\mathrm{EF}_{\mathrm{HC}}{ }^{\mathrm{c}} \\
\mathrm{g}(\mathrm{kg} \text { fuel })^{-1}\end{array}$ \\
\hline Euro III HDT in this study & $26 \pm 6^{d}$ & roadside & $43.3 \pm 31.5$ & $7.5 \pm 4.1$ & $36.0 \pm 13.2$ & $0.8 \pm 1.3$ \\
\hline $\begin{array}{l}\text { Euro III bus } \\
\text { (Hallquist et al., 2013) }\end{array}$ & acceleration & roadside & $16.1 \pm 9.7$ & - & $16.1 \pm 16.1$ & $<13$ \\
\hline \multirow[t]{2}{*}{$\begin{array}{l}\text { Euro III bus } \\
\text { (Pirjola et al., 2016) }\end{array}$} & $\begin{array}{c}\leq 25 \\
\text { (bus depot) }\end{array}$ & plume chasing & $12.7 \pm 1.8^{\mathrm{d}}$ & - & - & - \\
\hline & $\begin{array}{c}\leq 45 \\
\text { (bus line) }\end{array}$ & plume chasing & 20.5 & - & - & - \\
\hline $\begin{array}{l}\text { Euro III bus } \\
\text { with DPF + SCR } \\
\text { (Watne et al., 2018) }\end{array}$ & acceleration & roadside & - & - & $13 \pm 10$ & 0.02 \\
\hline $\begin{array}{l}\text { Euro III HDV } \\
\text { (Lau et al., 2015) }\end{array}$ & $64 \pm 13^{d}$ & plume chasing & - & $24 \pm 4$ & - & - \\
\hline $\begin{array}{l}\text { Euro III and IV HDV } \\
\text { (Kousoulidou et al., 2008) }\end{array}$ & - & model & - & 14 & - & - \\
\hline $\begin{array}{l}\text { Euro III HGV } \\
\text { (Carslaw et al., 2011) }\end{array}$ & average at 31 & remote sensing & $16.2 \pm 1.0^{f}$ & - & - & - \\
\hline $\begin{array}{l}\text { Euro III HGV } \\
\text { (Carslaw and Rhys-Tyler, 2013) }\end{array}$ & $28-60$ & remote sensing & - & $24.1 \pm 4.7$ & - & - \\
\hline Euro IV HDT in this study & $23 \pm 8^{d}$ & roadside & $19.8 \pm 10.1$ & $2.7 \pm 2.9$ & $22.1 \pm 10.3$ & $0.7 \pm 1.1$ \\
\hline $\begin{array}{l}\text { Euro IV bus } \\
\text { (Hallquist et al., 2013) }\end{array}$ & acceleration & roadside & $12.9 \pm 6.5$ & - & $16.1 \pm 16.1$ & $<13$ \\
\hline $\begin{array}{l}\text { Euro IV bus } \\
\text { with EGR + DPF } \\
\text { (Pirjola et al., 2016) }\end{array}$ & $\begin{array}{c}\leq 25 \\
\text { (bus depot) }\end{array}$ & plume chasing & $23.4 \pm 6.1^{\mathrm{d}}$ & - & - & - \\
\hline $\begin{array}{l}\text { Euro IV bus with SCR } \\
\text { (Watne et al., 2018) }\end{array}$ & roadside & acceleration & - & - & $220-230$ & $0.3-0.6$ \\
\hline $\begin{array}{l}\text { Euro IV HDV } \\
\text { (Lau et al., 2015) }\end{array}$ & $64 \pm 13^{\mathrm{d}}$ & plume chasing & - & $28 \pm 5$ & - & - \\
\hline $\begin{array}{l}\text { Euro IV HGV } \\
\text { (Carslaw et al., 2011) }\end{array}$ & average at 31 & remote sensing & $10.3 \pm 1.4^{\mathrm{f}}$ & - & - & - \\
\hline $\begin{array}{l}\text { Euro IV HGV } \\
\text { (Carslaw and Rhys-Tyler, 2013) }\end{array}$ & $28-60$ & remote sensing & - & $3.1 \pm 0.7$ & - & - \\
\hline Euro V HDT in this study & $27 \pm 7^{\mathrm{d}}$ & roadside & $22.2 \pm 3.8$ & $6.0 \pm 2.8$ & $22.8 \pm 5.1$ & $0.9 \pm 0.4$ \\
\hline $\begin{array}{l}\text { Euro V bus } \\
\text { (Hallquist et al., 2013) }\end{array}$ & acceleration & roadside & $35.5 \pm 9.7$ & - & $9.7 \pm 3.2$ & $<13$ \\
\hline $\begin{array}{l}\text { Euro V bus with SCR } \\
\text { (Liu et al., 2019) }\end{array}$ & $\begin{array}{l}\text { stop and go } \\
\text { (bus stop) }\end{array}$ & roadside & $9.8 \pm 3.5^{\mathrm{d}}$ & $3.7 \pm 1.5^{\mathrm{d}}$ & $28^{\mathrm{e}}$ & $2.2^{\mathrm{e}}$ \\
\hline $\begin{array}{l}\text { Euro V HDV } \\
\text { (Lau et al., 2015) }\end{array}$ & $64 \pm 13^{d}$ & plume chasing & - & $40 \pm 14$ & - & - \\
\hline $\begin{array}{l}\text { Euro V HDV } \\
\text { (Kousoulidou et al., 2008) }\end{array}$ & - & model & - & 18 & - & - \\
\hline $\begin{array}{l}\text { Euro V HGV } \\
\text { (Carslaw et al., 2011) }\end{array}$ & average at 31 & remote sensing & $13.3 \pm 5.8^{f}$ & - & - & - \\
\hline
\end{tabular}


Table 2. Continued.

\begin{tabular}{|c|c|c|c|c|c|c|}
\hline Vehicle type & $\begin{array}{c}\text { Speed } \\
\mathrm{km} \mathrm{h}^{-1}\end{array}$ & Method & $\begin{array}{c}\mathrm{EF}_{\mathrm{NO}_{x}}{ }^{\mathrm{b}} \\
\mathrm{g}(\mathrm{kg} \text { fuel })^{-1}\end{array}$ & $\begin{array}{c}\mathrm{EF}_{\mathrm{NO}_{2}} / \mathrm{EF}_{\mathrm{NO}_{x}} \mathrm{~b} \\
\text { mass ratio } \\
\%\end{array}$ & $\begin{array}{c}\mathrm{EF}_{\mathrm{CO}}^{\mathrm{c}} \\
\mathrm{g}(\mathrm{kg} \text { fuel })^{-1}\end{array}$ & $\begin{array}{c}\mathrm{EF}_{\mathrm{HC}}{ }^{\mathrm{c}} \\
\mathrm{g}(\mathrm{kg} \text { fuel })^{-1}\end{array}$ \\
\hline $\begin{array}{l}\text { Euro V HGV } \\
\text { (Carslaw and Rhys-Tyler, 2013) }\end{array}$ & $28-60$ & remote sensing & - & $3.7 \pm 0.7$ & - & - \\
\hline EEV HDT in this study & $25 \pm 8^{\mathrm{d}}$ & roadside & $13.6 \pm 6.7$ & $6.3 \pm 3.7$ & $18.0 \pm 10.1$ & $0.2 \pm 0.4$ \\
\hline $\begin{array}{l}\text { EEV bus with EGR + DPF } \\
\text { (Pirjola et al., 2016) }\end{array}$ & $\begin{array}{c}\leq 25 \\
\text { (bus depot) }\end{array}$ & plume chasing & $32.9 \pm 7.6^{\mathrm{d}}$ & - & - & - \\
\hline $\begin{array}{l}\text { EEV bus with SCR } \\
\text { (Pirjola et al., 2016) }\end{array}$ & $\begin{array}{c}\leq 25 \\
\text { (bus depot) }\end{array}$ & plume chasing & $39.8 \pm 4.2^{\mathrm{d}}$ & - & - & - \\
\hline Euro VI HDT in this study & $29 \pm 8^{d}$ & roadside & $3.1 \pm 1.0$ & $22.5 \pm 4.2$ & $15.5 \pm 2.2$ & $1.0 \pm 0.5$ \\
\hline $\begin{array}{l}\text { Euro VI HDT } \\
\text { (Grigoratos et al., 2019) }\end{array}$ & $65-74$ & PEMS & $0.3-31.3$ & - & $2.8-22.3$ & $0.3-3.1$ \\
\hline $\begin{array}{l}\text { Euro VI HDV } \\
\text { (Kousoulidou et al., 2008) }\end{array}$ & - & model & - & 35 & - & - \\
\hline $\begin{array}{l}\text { Euro VI HDV } \\
\text { (Moody and Tate, 2017) }\end{array}$ & driving cycle & PEMS & $2.2^{\mathrm{f}}$ & - & - & - \\
\hline $\begin{array}{l}\text { HDT without available Euro } \\
\text { type information }\end{array}$ & $27 \pm 7^{d}$ & roadside & $7.8 \pm 4.5$ & $13.9 \pm 6.3$ & $20.7 \pm 5.6$ & $0.8 \pm 0.6$ \\
\hline Total Swedish HDT & $28 \pm 7^{\mathrm{d}}$ & roadside & $10.7 \pm 1.8$ & $15.9 \pm 2.5$ & $18.6 \pm 1.9$ & $0.9 \pm 0.3$ \\
\hline Total non-Swedish HDT & $26 \pm 8^{d}$ & roadside & $13.0 \pm 2.5$ & $12.7 \pm 3.0$ & $19.1 \pm 3.0$ & $0.9 \pm 0.6$ \\
\hline \multicolumn{7}{|c|}{ Non-European HDV with different ATSs } \\
\hline $\begin{array}{l}\text { Heavy-duty HDV } \\
\text { with DPF + SCR } \\
\text { (Thiruvengadam et al., 2015) }\end{array}$ & driving cycle & $\begin{array}{c}\text { chassis } \\
\text { dynamometer }\end{array}$ & $3.8-27.8^{\mathrm{f}}$ & - & $0.1-13.4^{\mathrm{f}}$ & $<0.64^{\mathrm{f}}$ \\
\hline $\begin{array}{l}\text { HDV with DPF + SCR } \\
\text { (Jiang et al., 2018) }\end{array}$ & driving cycle & $\begin{array}{c}\text { chassis } \\
\text { dynamometer }\end{array}$ & $0.2-66.4^{\mathrm{f}}$ & - & $0.006-14.9^{\mathrm{f}}$ & $<1.3^{\mathrm{f}}$ \\
\hline $\begin{array}{l}\text { HDV with DOC + DPF + SCR } \\
\text { (Quiros et al., 2016) }\end{array}$ & $12.7-85.6$ & $\begin{array}{l}\text { mobile } \\
\text { laboratory }\end{array}$ & $1.7-11.8^{\mathrm{f}}$ & - & $0.9-2.8^{\mathrm{f}}$ & $0.1-0.4^{\mathrm{f}}$ \\
\hline HDV (May et al., 2014) & driving cycle & $\begin{array}{l}\text { chassis } \\
\text { dynamometer }\end{array}$ & $30-43$ & - & - & - \\
\hline $\begin{array}{l}\text { HDV with SCR } \\
\text { (May et al., 2014) }\end{array}$ & & $\begin{array}{c}\text { chassis } \\
\text { dynamometer }\end{array}$ & 11 & - & - & - \\
\hline $\begin{array}{l}\text { HDV fleet average } \\
\text { (Haugen et al., 2018) }\end{array}$ & $22.5 \pm 0.9$ & remote sensing & $12.4 \pm 0.6$ & 8.9 & $5.9 \pm 0.9$ & $2.2 \pm 0.4$ \\
\hline $\begin{array}{l}\text { HDT (model year 2004-2006) } \\
\text { (Preble et al., 2015) }\end{array}$ & $\begin{array}{l}\text { accelerating or } \\
\text { cruise at } 48\end{array}$ & roadside & $16.5 \pm 1.7$ & $3.4 \pm 1.8$ & - & - \\
\hline $\begin{array}{l}\text { HDT with SCR + DPF } \\
\text { (model year 2010-2013) } \\
\text { (Preble et al., 2015) }\end{array}$ & & roadside & $5.1 \pm 1.2$ & $22.1 \pm 8.4$ & - & - \\
\hline $\begin{array}{l}\text { HDT (model year 2001) } \\
\text { (Burgard et al., 2006) }\end{array}$ & $5-25$ & roadside & - & $9.1 \pm 0.5$ & $26.0 \pm 2.1$ & $1.8 \pm 0.6$ \\
\hline $\begin{array}{l}\text { HDT (model year 2000) } \\
\text { (Burgard et al., 2006) }\end{array}$ & $20-40$ & roadside & - & $6.1 \pm 0.1$ & $37.9 \pm 1.6$ & $3.3 \pm 0.4$ \\
\hline $\begin{array}{l}\text { Fleet average in } 2006 \\
\text { (Bishop and Stedman, 2008) }\end{array}$ & $28-36$ & roadside & $2-5$ & - & $17-24$ & $1.9-2.3$ \\
\hline
\end{tabular}


Table 2. Continued.

\begin{tabular}{|c|c|c|c|c|c|c|}
\hline Vehicle type & $\begin{array}{c}\text { Speed } \\
\mathrm{km} \mathrm{h}^{-1}\end{array}$ & Method & $\begin{array}{c}\mathrm{EF}_{\mathrm{NO}_{x}}{ }^{\mathrm{b}} \\
\mathrm{g}(\mathrm{kg} \text { fuel })^{-1}\end{array}$ & $\begin{array}{c}\mathrm{EF}_{\mathrm{NO}_{2}} / \mathrm{EF}_{\mathrm{NO}_{x}}{ }^{\mathrm{b}} \\
\text { mass ratio } \\
\%\end{array}$ & $\begin{array}{c}\mathrm{EF}_{\mathrm{CO}}{ }^{\mathrm{c}} \\
\mathrm{g}(\mathrm{kg} \text { fuel })^{-1}\end{array}$ & $\begin{array}{c}\mathrm{EF}_{\mathrm{HC}}{ }^{\mathrm{c}} \\
\mathrm{g}(\mathrm{kg} \text { fuel })^{-1}\end{array}$ \\
\hline $\begin{array}{l}\text { HDT fleet average } \\
\text { (Dallmann et al., 2012) }\end{array}$ & 65 & roadside & $28 \pm 1.5$ & 7.0 & $8.0 \pm 1.2$ & - \\
\hline $\begin{array}{l}\text { HDT (mean model year 2004) } \\
\text { (Bishop et al., 2013) }\end{array}$ & $22.2 \pm 0.4$ & remote sensing & $20.6 \pm 0.6^{\mathrm{d}}$ & 9.7 & $8.2 \pm 0.6^{\mathrm{d}}$ & $3.7 \pm 0.1^{\mathrm{d}}$ \\
\hline $\begin{array}{l}\text { HDT (mean model year 2009) } \\
\text { (Bishop et al., 2013) }\end{array}$ & $7.8 \pm 0.1$ & remote sensing & $19.9 \pm 0.3^{\mathrm{d}}$ & 9.0 & $7.3 \pm 0.5^{\mathrm{d}}$ & $0.6 \pm 0.6^{\mathrm{d}}$ \\
\hline
\end{tabular}

${ }^{a}$ Given errors are at $95 \%$ CI. ${ }^{b}$ In $\mathrm{NO}_{2}$ equivalents. ${ }^{\mathrm{c}} \mathrm{RSD}$ data. For the RSD data sets of multiple individuals, negative values were replaced by zero when calculating the averages. ${ }^{\mathrm{d}}$ Standard deviation. ${ }^{\mathrm{e}}$ Median. ${ }^{\mathrm{f}}$ Average fuel consumption of $0.26 \mathrm{~L} \mathrm{~km}^{-1}$ for HDV during long-haul and regional delivery tests (Rexeis et al., 2018); the density of $0.815 \mathrm{~kg} \mathrm{dm}^{-3}$ (Hallquist et al., 2013) for diesel particles was assumed.
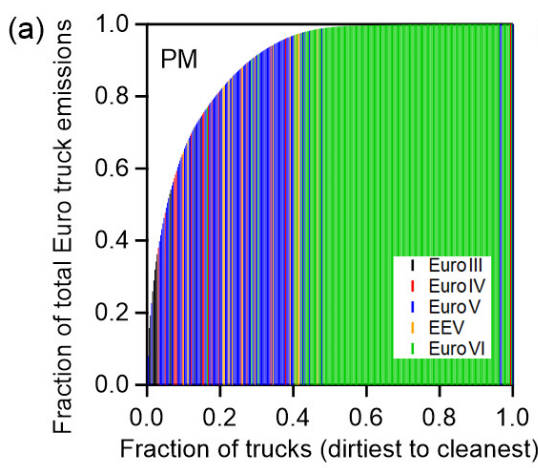

(c)

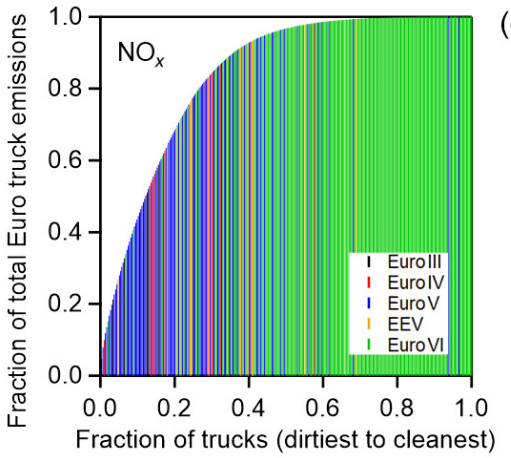

(b)

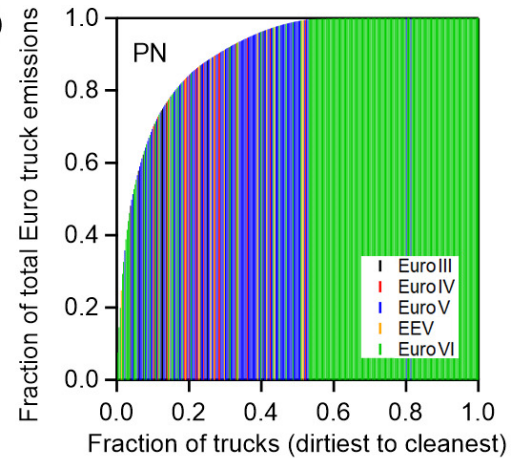

(d)

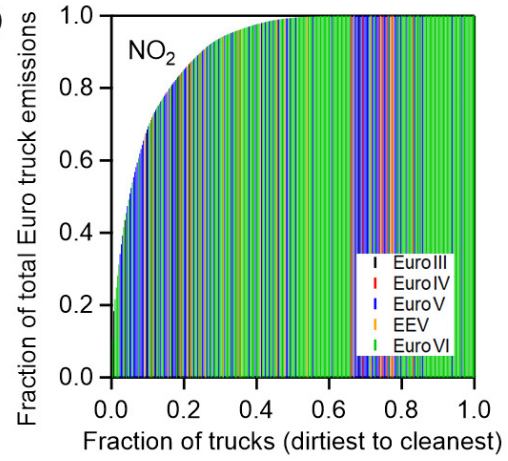

Figure 5. Cumulative emission factor distribution for (a) $\mathrm{PM}$, (b) $\mathrm{PN}$, (c) $\mathrm{NO}_{x}$, and (d) $\mathrm{NO}_{2}$ measured in HDT exhaust plumes with HDTs ranked from the highest to lowest in terms of emission factors.

To be consistent with previous studies, which overwhelmingly report average size distributions, we choose to utilize the average size distributions for the discussions below. The volatilities of particle emissions in the accumulation and nucleation modes have been evaluated by calculating the average $E_{P N}$ and $E F_{P M}$ fraction remaining (after heating) of particles emitted from Euro III-VI HDTs (Fig. S10). In general, the $\mathrm{EF}_{\mathrm{PN}}$ fraction remaining in the nucleation mode was lower than that in the accumulation mode across all HDTs in all Euro classes. In terms of particle mass, the nucleation mode and accumulation mode showed similar EFPM fractions remaining from Euro III to EEV HDTs, while Euro
VI HDTs had a much lower EFPM fraction remaining in the nucleation mode than in the accumulation mode. Compared with other Euro class HDTs, Euro VI HDTs had the lowest $\mathrm{EF}_{\mathrm{PN}}$ and $\mathrm{EF}_{\mathrm{PM}}$ fraction remaining in both nucleation and accumulation mode. Around $94 \%$ of the particles by number and $55 \%$ of the particles by mass (or volume) in total were evaporated. Alfoldy et al. (2009) reported that if the same amount of volatile mass in the nucleation mode and accumulation mode were inhaled, $48 \%$ and $29 \%$ of the mass would deposit in the lung, respectively, implying that volatile mass in the nucleation mode would exert a 1.5 times stronger effect. 


\subsection{Emissions from high emitters}

Figure 5 shows the cumulative emission distributions for PM, $\mathrm{PN}, \mathrm{NO}_{x}$, and $\mathrm{NO}_{2}$ emissions, with HDTs ranked in order from dirtiest to cleanest. The plots show a significant skewness towards a small fraction of HDTs with a high fraction of total emissions (deviation from 1:1 line) for each pollutant, indicating the importance of "high emitters". The disproportionate skewed distribution of pollutants is a common feature of on-road emission measurements (Preble et al., 2018, 2015; Dallmann et al., 2012). The highest-emitting $10 \%$ of HDTs in each pollutant were responsible for $65 \%$ of total PM, $70 \%$ of total PN, $44 \%$ of total $\mathrm{NO}_{x}$ emissions, and $69 \%$ of total $\mathrm{NO}_{2}$. The distribution of $\mathrm{NO}_{x}$ has the least skewness compared with the other pollutants. If the $10 \%$ highest emitters for each pollutant were removed, the corresponding average $\mathrm{EF}$ for $\mathrm{PM}, \mathrm{PN}, \mathrm{NO}_{x}$, and $\mathrm{NO}_{2}$ would decrease by $62 \%, 67 \%, 38 \%$, and $66 \%$, respectively. However, the high emitters for each pollutant are different. For example, Euro III HDTs account for $70 \%$ and $67 \%$ of the top $3 \%$ emitters for PM and BC emissions, respectively, while Euro VI HDTs account for $80 \%$ and $56 \%$ of the top $3 \%$ emitters for $\mathrm{PN}$ and $\mathrm{NO}_{2}$ emissions, respectively. Here, top $3 \%$ emitters were chosen as the reference because Euro III HDTs only accounted for $3 \%$ of the total number of HDTs. Lau et al. (2015) similarly reported that not all high emitters were members of the lower Euro classes and that high emitters for a particular pollutant may not simultaneously be high emitters for other pollutants.

\subsection{Fleet characteristics}

Figure 6a-d show the average EFs of PM, PN, BC, and $\mathrm{NO}_{x}$ with respect to the registration year of the HDTs. Triennial average EFs were calculated, with truck registration years divided into 5 bins (2002-2005, 2006-2008, 20092011, 2012-2014, and 2015-2017). The arrows in Fig. 6d show the years that the particular type of HDTs examined in this study was first registered. Coupled with the possible phaseout of older fleets, the HDTs with more advanced engines gradually accounted for a higher proportion of the total fleet. There is a significant improvement during the last years and the transition to widespread adoption of Euro VI will take real-world on-road emissions into a new era of much lower contributions to air pollution.

To estimate, for each Euro class, the typical contribution of air pollution emissions, we utilized the number of kilometres driven by HDTs on Swedish roads. During 2018, $4.1 \times 10^{9}$ and $9.2 \times 10^{8} \mathrm{~km}$ were driven by Swedish and nonSwedish diesel HDTs on Swedish roads, contributing to $82 \%$ and $18 \%$ to the total distances travelled by diesel HDTs, respectively (Fig. 7a). The numbers of kilometres driven by Swedish Euro 0, Euro I, Euro II, Euro III, Euro IV, Euro V, and Euro VI diesel HDTs were $2.8 \times 10^{7}, 5.0 \times 10^{6}, 5.4 \times 10^{7}$, $2.0 \times 10^{8}, 3.1 \times 10^{8}, 1.3 \times 10^{9}$, and $2.2 \times 10^{9}$, respectively

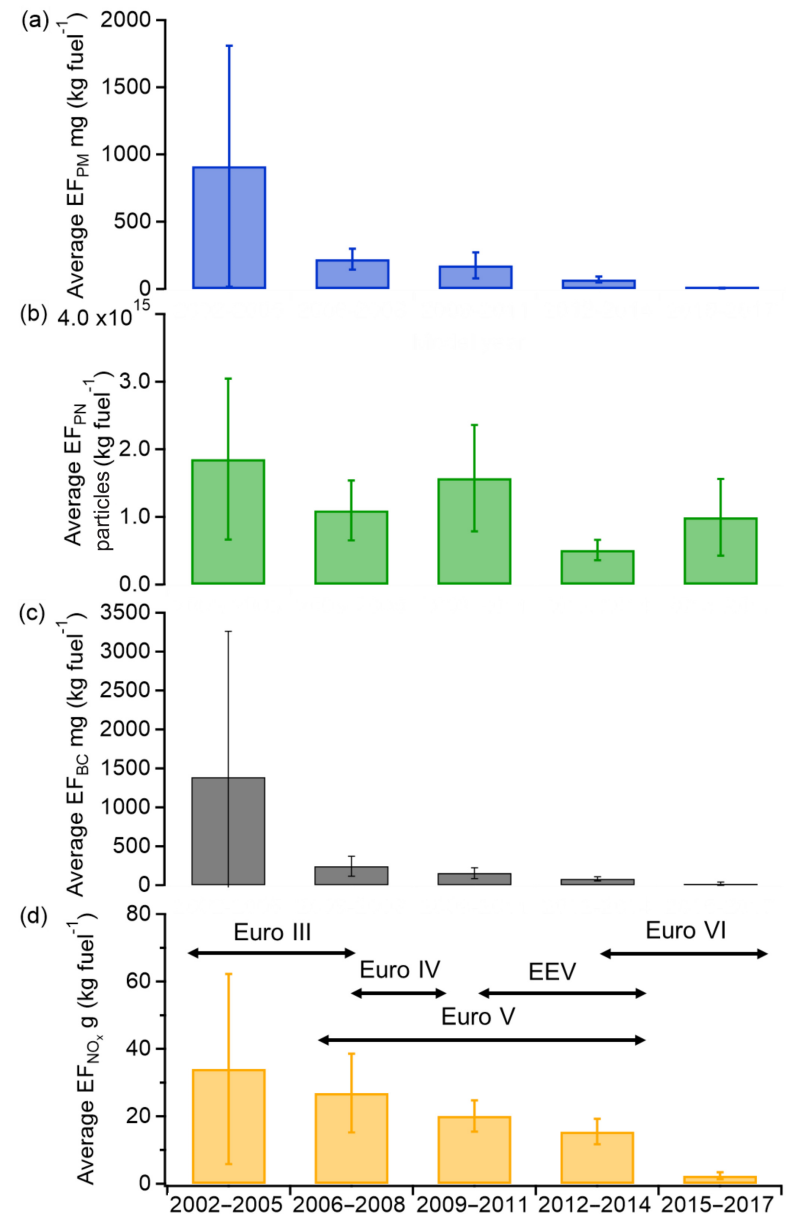

Figure 6. The average EFs of (a) $\mathrm{PM}$, (b) $\mathrm{PN}$, (c) $\mathrm{BC}$, and (d) $\mathrm{NO}_{x}$ with respect to the registration year of HDTs. Error bars represent the statistical $95 \%$ confidence interval. Black arrows mark the years that the particular type of HDT examined in this study was first registered.

(HBEFA 3.3, 2019). In Fig. 7b, the relative contributions of kilometres driven by Swedish Euro 0 to Euro VI HDTs are shown. Zhang et al. (2014) reported no statistically significant difference in fuel consumption among Euro II to Euro IV buses under a real-world typical bus driving cycle in Beijing. In this study, we assume the fuel consumption per kilometre and fuel density are the same across the different Euro class HDTs, and, adopting the average fuel-based EFs calculated in this study (Tables 1 and 2), the approximations of contributions of pollutants emitted from Swedish HDTs in each Euro class to the total PM, PN, BC, and $\mathrm{NO}_{x}$ emissions are depicted in Fig. 7c-f. Due to a lack of corresponding emission information, pollutant average EFs of Euro 0, Euro I, and Euro II HDTs were assumed to be at the same level as those of Euro III HDTs representing lower bound estimates. Euro 0-II HDTs accounted for less than $2.2 \%$ of the grand total distance driven but totally contributed to $16 \%$, $13 \%, 6 \%$, and $4 \%$ of $\mathrm{BC}, \mathrm{PM}, \mathrm{NO}_{x}$, and $\mathrm{PN}$ emissions. Euro 
(a)

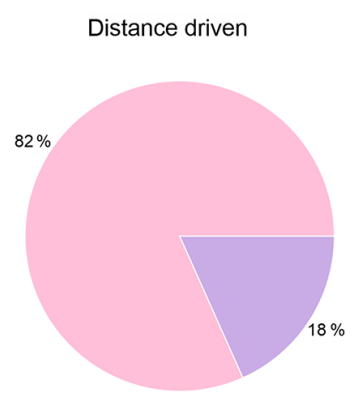

(c)

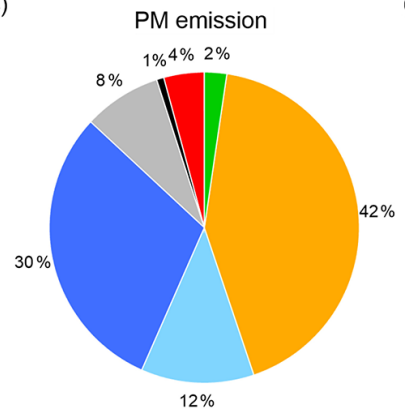

(d)

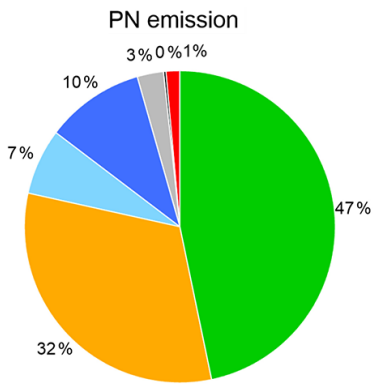

(b)

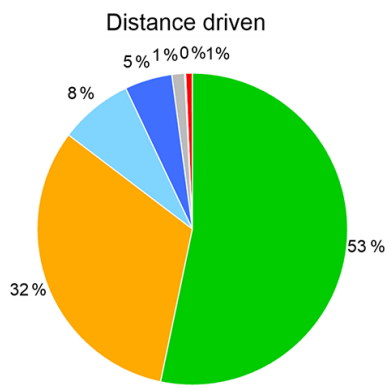

(e)

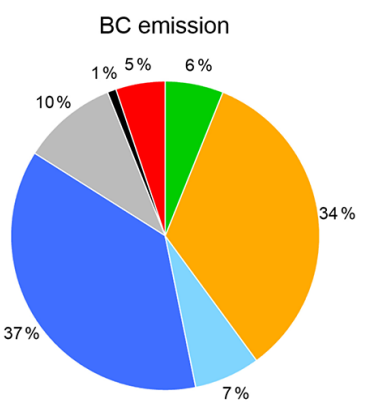

Swedish HDT

Non-Swedish HDT

Swedish Euro 0 HDT

Swedish Euro I HDT Swedish Euro II HDT Swedish Euro III HDT Swedish Euro V HDT Swedish Euro VIHDT Swedish Euro VI HDT

(f)

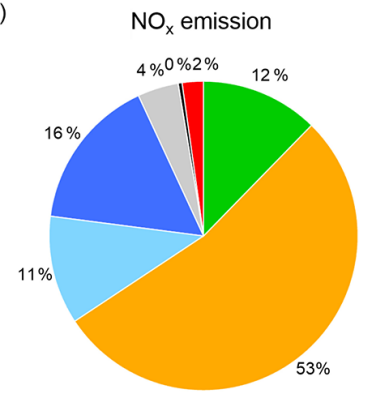

Figure 7. Relative contributions of kilometres driven by (a) Swedish and non-Swedish HDTs and (b) Swedish Euro 0, Euro I, Euro II, Euro III, Euro IV, Euro V, and Euro VI HDTs on Swedish roads during 2018. Approximation of contributions of pollutants emitted from Swedish HDTs in each Euro class to the total (c) PM, (d) PN, (e) BC, and (f) $\mathrm{NO}_{x}$ emissions.

III HDTs only accounted for $5 \%$ (Fig. 7b) of the total fleet but disproportionally contributed to $37 \%, 30 \%, 16 \%$, and $10 \%$ of $\mathrm{BC}, \mathrm{PM}, \mathrm{NO}_{x}$, and PN emissions. Euro IV HDTs also exhibited disproportionally high $\mathrm{PM}$ and $\mathrm{NO}_{x}$ emissions. A fraction of $32 \%$ of HDTs belonged to the Euro V category, they contributed to $53 \%, 42 \%, 34 \%$, and $32 \%$ of $\mathrm{NO}_{x}, \mathrm{PM}, \mathrm{BC}$, and $\mathrm{PN}$ emissions, respectively. Upgrading, replacing, or making Euro 0 to Euro V HDTs obsolete would be necessary for mitigating a large part of the PM, PN, BC, and $\mathrm{NO}_{x}$ emissions. Euro VI HDTs accounted for the highest fraction of the total fleet ( $53 \%$ ), but only contributed to $2 \%$, $6 \%, 12 \%$ and $47 \%$ of $\mathrm{PM}, \mathrm{BC}, \mathrm{NO}_{x}$, and $\mathrm{PN}$ emissions, indicating successful overall pollution reduction with the introduction of more Euro VI HDTs. Using the median EFs as references, the emission contributions from Euro VI HDTs to the total pollutant emissions would be even lower (Fig. S11). These data provide useful information to predict future pollutant emission trends and to guide policy analysis and implementation. Since the predicted transition in emissions from road transport would be significant, chemical transport model or cost-assessment models need to gain fast access to emission factors for new generation HDTs to be able to provide a better estimation of near-future air pollution levels.

\section{Atmospheric implications and conclusions}

The transition in the atmospheric emission of particles and gases from on-road HDTs caused by the modernization of the fleet is reported in this study. Particle emissions of PM, $\mathrm{BC}$, and to a lesser extent PN exhibited substantial reductions from Euro III to Euro VI HDTs (Jonckheere-Terpstra test, $p<0.01)$. The gaseous emissions of $\mathrm{NO}_{x}$ and $\mathrm{CO}$ also showed a significant decrease with respect to Euro class (Jonckheere-Terpstra test, $p<0.01$ ), while the HC emission was relatively low for all the HDT Euro class types. Compared with Euro III HDTs, Euro VI HDTs showed $99 \%$, $98 \%, 93 \%$, and $57 \%$ reductions of the average emission factors of $\mathrm{PM}, \mathrm{BC}, \mathrm{NO}_{x}$, and $\mathrm{CO}$, respectively. Although a significant reduction in $\mathrm{NO}_{x}$ emissions and a lower median $\mathrm{EF}_{\mathrm{NO}_{2}}$ were evident, the fraction of $\mathrm{NO}_{2}$ in the $\mathrm{NO}_{x}$ emissions increased continuously from Euro IV to Euro VI HDTs, and Euro VI HDTs were the dominant class of the top $3 \%$ emitters for $\mathrm{NO}_{2}$. PN showed the largest data scattering for Euro VI HDTs, though after evaporation of the volatile fraction SPN became less scattered. A plausible reason for this large variability in PN but not PM is the formation of nucleation mode particles containing more volatile compounds, which are more sensitive to individual driving and plume dilution conditions. Reducing particle mass by DPF is clearly important, but the consequence of doing so removes particle surface area available for condensation and may therefore favour nucleation mode particle formation if the precursors of these particles are not also reduced. Furthermore, due to the absence of larger particles, the coagulation rate is decreased and the nucleation mode particles formed can retain for a longer time in the atmosphere, which has a direct influence on the evaluation of near-road human exposure. 
Driving condition and engine technology affected the size distribution of particle number emissions. The average particle number size distributions of Euro III to EEV HDTs were bimodal with nucleation modes at $\sim 6-10 \mathrm{~nm}$ and accumulation modes at $\sim 50-80 \mathrm{~nm}$. Euro VI HDTs displayed nucleation-mode-dominant size distributions. Measurements of particle volatility revealed that Euro VI HDTs had the highest volatile fraction in both nucleation mode and accumulation mode compared to the other Euro classes. More detailed chemical composition information of this volatile fraction is needed to assess their potential impacts for health and formation of SOA.

We also found that a small number of high emitters contributed to a large fraction of the total emissions. The top $10 \%$ emitters in each pollutant category were responsible for $65 \%$ of total PM, $70 \%$ of total PN, $44 \%$ of total $\mathrm{NO}_{x}$, and $69 \%$ of total $\mathrm{NO}_{2}$ emissions, respectively. Euro III HDTs were the dominant top $3 \%$ emitters for PM and BC emissions, and Euro VI HDTs were the dominant top $3 \%$ emitters for $\mathrm{PN}$ and $\mathrm{NO}_{2}$ emissions.

In general, an overall pollution reduction has been achieved during the last years, and the transition to Euro VI adoption will take real-world on-road emissions into a new era of much lower contributions to air pollution. The emissions of $\mathrm{PM}, \mathrm{BC}$, and $\mathrm{NO}_{x}$ are predicted to further decrease in the future, while PN emissions may be subject to greater fluctuation and therefore be more challenging to control. Upgrading or phasing-out existing Euro 0 to Euro $\mathrm{V}$ vehicles and introducing more Euro VI HDTs would result in large pollution reductions. More intensive attention needs to be focused on SPN controls for Euro VI HDTs. A careful and more detailed examination of the impacts of fleet upgrades in terms of ambient pollutant levels and emission reduction targets for individual pollutants may be needed for further evaluation.

Data availability. The data used in this publication are available to the community, and they can be accessed by request to the corresponding author.

Supplement. The supplement related to this article is available online at: https://doi.org/10.5194/acp-20-1701-2020-supplement.

Author contributions. ÅMH designed the project; LZ, AMH, CMS, SMG, ÅS, MJ, HS, MH, and IW conducted the measurements; LZ, $\mathrm{CMS}$, and QL analysed data; LZ, ̊̊MH, MH, CKC, and BPL wrote the paper. All co-authors contributed to the discussion of the paper.

Competing interests. The authors declare that they have no conflict of interest.
Special issue statement. This article is part of the special issue "Air Quality Research at Street-Level (ACP/GMD inter-journal SI)". It is not associated with a conference.

Acknowledgements. This work was financed by Formas (2142013-1430) and was an initiative within the framework programme "Photochemical smog in China" financed by the Swedish Research Council (639-2013-6917). Chak K. Chan would like to acknowledge the support of the Science Technology and Innovation Committee of Shenzhen Municipality (project no. JCYJ20160401095857424).

Financial support. This research has been supported by the Formas (grant no. 214-2013-1430), the "Photochemical smog in China" financed by the Swedish Research Council (grant no. 639-20136917), and the Science Technology and Innovation Committee of Shenzhen Municipality (grant no. JCYJ20160401095857424).

Review statement. This paper was edited by Robert Harley and reviewed by two anonymous referees.

\section{References}

Alfoldy, B., Giechaskiel, B., Hofmann, W., and Drossinos, Y.: Size-distribution dependent lung deposition of diesel exhaust particles, J. Aerosol Sci., 40, 652-663, https://doi.org/10.1016/j.jaerosci.2009.04.009, 2009.

Amanatidis, S., Ntziachristos, L., Karjalainen, P., Saukko, E., Simonen, P., Kuittinen, N., Aakko-Saksa, P., Timonen, H., Ronkko, T., and Keskinen, J.: Comparative performance of a thermal denuder and a catalytic stripper in sampling laboratory and marine exhaust aerosols, Aerosol Sci. Tech., 52, 420-432, https://doi.org/10.1080/02786826.2017.1422236, 2018.

Arnold, F., Pirjola, L., Ronkko, T., Reichl, U., Schlager, H., Lahde, T., Heikkila, J., and Keskinen, J.: First online measurements of sulfuric acid gas in modern heavy-duty diesel engine exhaust: implications for nanoparticle formation, Environ. Sci. Technol., 46, 11227-11234, https://doi.org/10.1021/es302432s, 2012.

Ban-Weiss, G. A., Lunden, M. M., Kirchstetter, T. W., and Harley, R. A.: Measurement of black carbon and particle number emission factors from individual heavy-duty trucks, Environ. Sci. Technol., 43, 1419-1424, https://doi.org/10.1021/es8021039, 2009.

Bergmann, M., Kirchner, U., Vogt, R., and Benter, T.: On-road and laboratory investigation of low-level PM emissions of a modern diesel particulate filter equipped diesel passenger car, Atmos. Environ., 43, 1908-1916, https://doi.org/10.1016/j.atmosenv.2008.12.039, 2009.

Bishop, G. A. and Stedman, D. H.: A decade of on-road emissions measurements, Environ. Sci. Technol., 42, 1651-1656, https://doi.org/10.1021/es702413b, 2008.

Bishop, G. A., Peddle, A. M., Stedman, D. H., and Zhan, T.: Onroad emission measurements of reactive nitrogen compounds from three California cities, Environ. Sci. Technol., 44, 36163620, https://doi.org/10.1021/es903722p, 2010. 
Bishop, G. A., Schuchmann, B. G., and Stedman, D. H.: Heavy-duty truck emissions in the South Coast Air Basin of California, Environ. Sci. Technol., 47, 9523-9529, https://doi.org/10.1021/es401487b, 2013.

Bishop, G. A., Hottor-Raguindin, R., Stedman, D. H., McClintock, P., Theobald, E., Johnson, J. D., Lee, D. W., Zietsman, J., and Misra, C.: On-road heavy-duty vehicle emissions monitoring system, Environ. Sci. Technol., 49, 1639-1645, https://doi.org/10.1021/es505534e, 2015.

Biswas, S., Verma, V., Schauer, J. J., Cassee, F. R., Cho, A. K., and Sioutas, C.: Oxidative potential of semi-volatile and non-volatile particulate matter (PM) from heavy-duty vehicles retrofitted with emission control technologies, Environ. Sci. Technol., 43, 39053912, https://doi.org/10.1021/es9000592, 2009.

Bocchi, C., Bazzini, C., Fontana, F., Pinto, G., Martino, A., and Cassoni, F.: Characterization of urban aerosol: seasonal variation of mutagenicity and genotoxicity of $\mathrm{PM}_{2.5}, \mathrm{PM}_{1}$ and semi-volatile organic compounds, Mutat. Res., 809, 16-23, https://doi.org/10.1016/j.mrgentox.2016.07.007, 2016.

Burgard, D. A. and Provinsal, M. N.: On-road, in-use gaseous emission measurements by remote sensing of school buses equipped with diesel oxidation catalysts and diesel particulate filters, J. Air Waste Manage., 59, 1468-1473, https://doi.org/10.3155/10473289.59.12.1468, 2009.

Burgard, D. A., Bishop, G. A., Stedman, D. H., Gessner, V. H., and Daeschlein, C.: Remote sensing of in-use heavyduty diesel trucks, Environ. Sci. Technol., 40, 6938-6942, https://doi.org/10.1021/es060989a, 2006.

Campagnolo, D., Cattaneo, A., Corbella, L., Borghi, F., Del Buono, L., Rovelli, S., Spinazze, A., and Cavallo, D. M.: In-vehicle airborne fine and ultra-fine particulate matter exposure: The impact of leading vehicle emissions, Environ. Int., 123, 407-416, https://doi.org/10.1016/j.envint.2018.12.020, 2019.

Carslaw, D. C. and Rhys-Tyler, G.: New insights from comprehensive on-road measurements of $\mathrm{NO}_{x}, \mathrm{NO}_{2}$ and $\mathrm{NH}_{3}$ from vehicle emission remote sensing in London, UK, Atmos. Environ., 81, 339-347, https://doi.org/10.1016/j.atmosenv.2013.09.026, 2013.

Carslaw, D. C., Beevers, S. D., Tate, J. E., Westmoreland, E. J., and Williams, M. L.: Recent evidence concerning higher $\mathrm{NO}_{x}$ emissions from passenger cars and light-duty vehicles, Atmos. Environ., 45, 7053-7063, https://doi.org/10.1016/j.atmosenv.2011.09.063, 2011.

Carslaw, D. C., Farren, N. J., Vaughan, A. R., Drysdale, W. S., Young, S., and Lee, J. D.: The diminishing importance of nitrogen dioxide emissions from road vehicle exhaust, Atmos. Environ., 1, 100002, https://doi.org/10.1016/j.aeaoa.2018.100002, 2019.

Chen, L., Wang, Z., Liu, S., and Qu, L.: Using a chassis dynamometer to determine the influencing factors for the emissions of Euro VI vehicles, Transport. Res. D-Tr. E., 65, 564-573, https://doi.org/10.1016/j.trd.2018.09.022, 2018.

Cheung, H. H. Y., Tan, H., Xu, H., Li, F., Wu, C., Yu, J. Z., and Chan, C. K.: Measurements of non-volatile aerosols with a VTDMA and their correlations with carbonaceous aerosols in Guangzhou, China, Atmos. Chem. Phys., 16, 8431-8446, https://doi.org/10.5194/acp-16-8431-2016, 2016.

Clark, N. N., Gautam, M., Rapp, B. L., Lyons, D. W., Graboski, M. S., McCormick, L., Alleman, T. L., and Norton, P.: Diesel and cng transit bus emissions characterization by two chassis dy- namometer laboratories: Results and issues, Soc. Autom. Eng., 1999-01-1469, 1999.

Cui, M., Chen, Y., Feng, Y., Li, C., Zheng, J., Tian, C., Yan, C., and Zheng, M.: Measurement of PM and its chemical composition in real-world emissions from non-road and onroad diesel vehicles, Atmos. Chem. Phys., 17, 6779-6795, https://doi.org/10.5194/acp-17-6779-2017, 2017.

Dallmann, T. R., DeMartini, S. J., Kirchstetter, T. W., Herndon, S. C., Onasch, T. B., Wood, E. C., and Harley, R. A.: On-road measurement of gas and particle-phase pollutant emission factors for individual heavy-duty diesel trucks, Environ. Sci. Technol., 46, 8511-8518, https://doi.org/10.1021/es301936c, 2012.

Donahue, N. M., Robinson, A. L., Stanier, C. O., and Pandis, S. N.: Coupled partitioning, dilution, and chemical aging of semivolatile organics, Environ. Sci. Technol., 40, 2635-2643, https://doi.org/10.1021/es052297c, 2006.

Dreher, D. B. and Harley, R. A.: A fuel-based inventory for heavyduty diesel truck emissions, J. Air Waste Manage., 48, 352-358, https://doi.org/10.1080/10473289.1998.10463686, 1998.

Du, Y., Xu, X., Chu, M., Guo, Y., and Wang, J.: Air particulate matter and cardiovascular disease: the epidemiological, biomedical and clinical evidence, J. Thorac. Dis., 8, E8-E19, https://doi.org/10.3978/j.issn.2072-1439.2015.11.37 2016.

Edwards, R., Larivé, J., Rickeard, D., and Weindorf, W.: Wellto-Wheels analysis of future automotive fuels and powertrains in the European context: Well-to-Tank Appendix 2-Version 4a, Joint Research Centre of the European Commission, EUCAR, and CONCAWE, 1-133, https://doi.org/10.2790/95629, 2014.

EEA: Air Quality in Europe - 2018 Report. European Environment Agency Report No. 12/2018, ISSN 19778449, available at: https://www.eea.europa.eu/publications/ air-quality-in-europe-2018 (last access: 8 May 2019), 2018.

Franco, V., Kousoulidou, M., Muntean, M., Ntziachristos, L., Hausberger, S., and Dilara, P.: Road vehicle emission factors development: A review, Atmos. Environ., 70, 84-97, https://doi.org/10.1016/j.atmosenv.2013.01.006, 2013.

Gentner, D. R., Jathar, S. H., Gordon, T. D., Bahreini, R., Day, D. A., El Haddad, I., Hayes, P. L., Pieber, S. M., Platt, S. M., de Gouw, J., Goldstein, A. H., Harley, R. A., Jimenez, J. L., Prevot, A. S., and Robinson, A. L.: Review of Urban Secondary Organic Aerosol Formation from Gasoline and Diesel Motor Vehicle Emissions, Environ. Sci. Technol., 51, 10741093, https://doi.org/10.1021/acs.est.6b04509, 2017.

Gertler, A. W.: Diesel vs. gasoline emissions: Does PM from diesel or gasoline vehicles dominate in the US?, Atmos. Environ., 39, 2349-2355, https://doi.org/10.1016/j.atmosenv.2004.05.065, 2005.

Giechaskiel, B., Alfoldy, B., and Drossinos, Y.: A metric for health effects studies of diesel exhaust particles, J. Aerosol Sci., 40, 639-651, https://doi.org/10.1016/j.jaerosci.2009.04.008, 2009.

Giechaskiel, B., Mamakos, A., Andersson, J., Dilara, P., Martini, G., Schindler, W., and Bergmann, A.: Measurement of Automotive Nonvolatile Particle Number Emissions within the European Legislative Framework: A Review, Aerosol Sci. Tech., 46, 719749, https://doi.org/10.1080/02786826.2012.661103, 2012.

Giechaskiel, B., Schwelberger, M., Delacroix, C., Marchetti, M., Feijen, M., Prieger, K., Andersson, S., and Karlsson, H. L.: Experimental assessment of solid particle number Portable Emissions Measurement Systems (PEMS) for heavy- 
duty vehicles applications, J. Aerosol Sci., 123, 161-170, https://doi.org/10.1016/j.jaerosci.2018.06.014, 2018.

Gkatzelis, G. I., Papanastasiou, D. K., Florou, K., Kaltsonoudis, C., Louvaris, E., and Pandis, S. N.: Measurement of nonvolatile particle number size distribution, Atmos. Meas. Tech., 9, 103-114, https://doi.org/10.5194/amt-9-103-2016, 2016.

Grigoratos, T., Fontaras, G., Giechaskiel, B., and Zacharof, N.: Real-world emissions performance of heavy-duty Euro VI diesel vehicles, Atmos. Environ., 201, 348-359, https://doi.org/10.1016/j.atmosenv.2018.12.042, 2019.

Guo, J. D., Ge, Y. S., Hao, L. J., Tan, J. W., Li, J. Q., and Feng, X. Y.: On-road measurement of regulated pollutants from diesel and $\mathrm{CNG}$ buses with urea selective catalytic reduction systems, Atmos. Environ., 99, 1-9, https://doi.org/10.1016/j.atmosenv.2014.07.032, 2014.

Hak, C. S., Hallquist, M., Ljungstrom, E., Svane, M., and Pettersson, J. B. C.: A new approach to in-situ determination of roadside particle emission factors of individual vehicles under conventional driving conditions, Atmos. Environ., 43, 2481-2488, https://doi.org/10.1016/j.atmosenv.2009.01.041, 2009.

Hallquist, Å. M., Jerksjö, M., Fallgren, H., Westerlund, J., and Sjödin, Å.: Particle and gaseous emissions from individual diesel and CNG buses, Atmos. Chem. Phys., 13, 5337-5350, https://doi.org/10.5194/acp-13-5337-2013, 2013.

HBEFA3.3: available online at: http://www.hbefa.net, last access: 10 May 2019.

Hallquist, M., Wenger, J. C., Baltensperger, U., Rudich, Y., Simpson, D., Claeys, M., Dommen, J., Donahue, N. M., George, C., Goldstein, A. H., Hamilton, J. F., Herrmann, H., Hoffmann, T., Iinuma, Y., Jang, M., Jenkin, M. E., Jimenez, J. L., Kiendler-Scharr, A., Maenhaut, W., McFiggans, G., Mentel, Th. F., Monod, A., Prévôt, A. S. H., Seinfeld, J. H., Surratt, J. D., Szmigielski, R., and Wildt, J.: The formation, properties and impact of secondary organic aerosol: current and emerging issues, Atmos. Chem. Phys., 9, 5155-5236, https://doi.org/10.5194/acp9-5155-2009, 2009.

Haugen, M. J., Bishop, G. A., Thiruvengadam, A., and Carder, D. K.: Evaluation of Heavy-and Medium-Duty On-Road Vehicle Emissions in California's South Coast Air Basin, Environ. Sci. Technol., 52, 13298-13305, https://doi.org/10.1021/acs.est.8b03994, 2018.

He, C., Li, J., Ma, Z., Tan, J., and Zhao, L.: High $\mathrm{NO}_{2} / \mathrm{NO}_{x}$ emissions downstream of the catalytic diesel particulate filter: An influencing factor study, J. Environ. Sci.-China, 35, 55-61, https://doi.org/10.1016/j.jes.2015.02.009, 2015.

He, L., Hu, J., Zhang, S., Wu, Y., Guo, X., Guo, X., Song, J., Zu, L., Zheng, X., and Bao, X.: Investigating real-world emissions of China's heavy-duty diesel trucks: Can SCR effectively mitigate NOx emissions for highway trucks, Aerosol Air. Qual. Res., 17, 2585-2594, https://doi.org/10.4209/aaqr.2016.12.0531, 2017.

Heeb, N. V., Schmid, P., Kohler, M., Gujer, E., Zennegg, M., Wenger, D., Wichser, A., Ulrich, A., Gfeller, U., Honegger, P., Zeyer, K., Emmenegger, L., Petermann, J. L., Czerwinski, J., Mosimann, T., Kasper, M., and Mayer, A.: Impact of low- and high-oxidation diesel particulate filters on genotoxic exhaust constituents, Environ. Sci. Technol., 44, 1078-1084, https://doi.org/10.1021/es9019222, 2010.

Herner, J. D., Hu, S., Robertson, W. H., Huai, T., Collins, J. F., Dwyer, H., and Ayala, A.: Effect of advanced af- tertreatment for $\mathrm{PM}$ and $\mathrm{NO}_{x}$ control on heavy-duty diesel truck emissions, Environ. Sci. Technol., 43, 5928-5933, https://doi.org/10.1021/es9008294, 2009.

Herner, J. D., Hu, S., Robertson, W. H., Huai, T., Chang, M.-C. O., Rieger, P., and Ayala, A.: Effect of advanced aftertreatment for $\mathrm{PM}$ and $\mathrm{NO}_{x}$ reduction on heavy-duty diesel engine ultrafine particle emissions, Environ. Sci. Technol., 45, 2413-2419, https://doi.org/10.1021/es102792y, 2011.

Heywood, J. B. Internal Combustion Engine Fundamentals, McGraw-Hill Book Co., New York, 1988.

Huffman, J. A., Ziemann, P. J., Jayne, J. T., Worsnop, D. R., and Jimenez, J. L.: Development and characterization of a fast-stepping/scanning thermodenuder for chemically-resolved aerosol volatility measurements, Aerosol Sci. Tech., 42, 395407, https://doi.org/10.1080/02786820802104981, 2008.

Janhäll, S. and Hallquist, M.: A novel method for determination of size-resolved, submicrometer particle traffic emission factors, Environ. Sci. Technol., 39, 7609-7615, https://doi.org/10.1021/es048208y, 2005.

Jarvinen, A., Timonen, H., Karjalainen, P., Bloss, M., Simonen, P., Saarikoski, S., Kuuluvainen, H., Kalliokoski, J., Dal Maso, M., Niemi, J. V., Keskinen, J., and Ronklo, T.: Particle emissions of Euro VI, EEV and retrofitted EEV city buses in real traffic, Environ. Pollut., 250, 708-716, https://doi.org/10.1016/j.envpol.2019.04.033, 2019.

Jiang, Y., Yang, J., Cocker III, D., Karavalakis, G., Johnson, K. C., and Durbin, T. D.: Characterizing emission rates of regulated pollutants from model year 2012+ heavy-duty diesel vehicles equipped with DPF and SCR systems, Sci. Total Environ., 619620, 765-771, https://doi.org/10.1016/j.scitotenv.2017.11.120, 2018.

Kittelson, D. B., Watts, W. F., and Johnson, J.: Diesel aerosol sampling methodology - CRC E-43: final report, University of Minnesota, Report for the Coordinating Research Council, available at: https://www.crcao.com (last access: 3 February 2020), 2002.

Ko, J., Myung, C. L., and Park, S.: Impacts of ambient temperature, DPF regeneration, and traffic congestion on $\mathrm{NO}_{x}$ emissions from a Euro 6-compliant diesel vehicle equipped with an LNT under real-world driving conditions, Atmos. Environ., 200, 1-14, https://doi.org/10.1016/j.atmosenv.2018.11.029, 2019.

Kousoulidou, M., Ntziachristos, L., Mellios, G., and Samaras, Z.: Road-transport emission projections to 2020 in European urban environments, Atmos. Environ., 42, 7465-7475, https://doi.org/10.1016/j.atmosenv.2008.06.002, 2008.

Kozawa, K. H., Park, S. S., Mara, S. L., and Herner, J. D.: Verifying emission reductions from heavy-duty diesel trucks operating on Southern California freeways, Environ. Sci. Technol., 48, 14751483, https://doi.org/10.1021/es4044177, 2014.

Lau, C. F., Rakowska, A., Townsend, T., Brimblecombe, P., Chan, T. L., Yam, Y. S., Mocnik, G., and Ning, Z.: Evaluation of diesel fleet emissions and control policies from plume chasing measurements of on-road vehicles, Atmos. Environ., 122, 171-182, https://doi.org/10.1016/j.atmosenv.2015.09.048, 2015.

Le Breton, M., Psichoudaki, M., Hallquist, M., Watne, A., Lutz, A., and Hallquist, Å.: Application of a FIGAERO ToF CIMS for on-line characterization of real-world fresh and aged particle emissions from buses, Aerosol Sci. Tech., 53, 244-259, https://doi.org/10.1080/02786826.2019.1566592, 2019. 
Li, X., Dallmann, T. R., May, A. A., Stanier, C. O., Grieshop, A. P., Lipsky, E. M., Robinson, A. L., and Presto, A. A.: Size distribution of vehicle emitted primary particles measured in a traffic tunnel, Atmos. Environ., 191, 9-18, https://doi.org/10.1016/j.atmosenv.2018.07.052, 2018.

Liu, Q., Hallquist, Å. M., Fallgren, H., Jerksjö, M., Jutterström, S., Salberg, H., Hallquist, M., Le Breton, M., Pei, X., and Pathak, R. K.: Roadside assessment of a modern city bus fleet: Gaseous and particle emissions, Atmos. Environ., 3, 100044, https://doi.org/10.1016/j.aeaoa.2019.100044, 2019.

Liu, T., Zhou, L., Liu, Q., Lee, B. P., Yao, D., Lu, H., Lyu, X., Guo, H., and Chan, C. K.: Secondary organic aerosol formation from urban roadside air in Hong Kong, Environ. Sci. Technol., 53, 3001-3009, https://doi.org/10.1021/acs.est.8b06587, 2019.

Liu, Z. G., Vasys, V. N., Dettmann, M. E., Schauer, J. J., Kittelson, D. B., and Swanson, J.: Comparison of Strategies for the Measurement of Mass Emissions from Diesel Engines Emitting Ultra-Low Levels of Particulate Matter, Aerosol Sci. Tech., 43, 1142-1152, https://doi.org/10.1080/02786820903219035, 2009.

Lv, Y., Li, X., Xu, T. T., Cheng, T. T., Yang, X., Chen, J. M., Iinuma, Y., and Herrmann, H.: Size distributions of polycyclic aromatic hydrocarbons in urban atmosphere: sorption mechanism and source contributions to respiratory deposition, Atmos. Chem. Phys., 16, 2971-2983, https://doi.org/10.5194/acp16-2971-2016, 2016.

Mahmoudzadeh Andwari, A., Pesiridis, A., Esfahanian, V., Salavati-Zadeh, A., Karvountzis-Kontakiotis, A., and Muralidharan, V.: A comparative study of the effect of turbo compounding and ORC waste heat recovery systems on the performance of a turbocharged heavy-duty diesel engine, Energies, 10, 1087, https://doi.org/10.3390/en10081087, 2017.

Manigrasso, M., Vernale, C., and Avino, P.: Traffic aerosol lobar doses deposited in the human respiratory system, Environ. Sci. Pollut. R., 24, 13866-13873, https://doi.org/10.1007/s11356015-5666-1, 2017.

Maricq, M. M.: Chemical characterization of particulate emissions from diesel engines: A review, J. Aerosol Sci., 38, 1079-1118, https://doi.org/10.1016/j.jaerosci.2007.08.001, 2007.

Maricq, M. M. and Ning, X.: The effective density and fractal dimension of soot particles from premixed flames and motor vehicle exhaust, J. Aerosol Sci., 35, 1251-1274, https://doi.org/10.1016/j.jaerosci.2004.05.002, 2004.

Martinet, S., Liu, Y., Louis, C., Tassel, P., Perret, P., Chaumond, A., and Andre, M.: Euro 6 Unregulated Pollutant Characterization and Statistical Analysis of After-Treatment Device and Driving-Condition Impact on Recent PassengerCar Emissions, Environ. Sci. Technol., 51, 5847-5855, https://doi.org/10.1021/acs.est.7b00481, 2017.

Martini, G., Giechaskiel, B., and Dilara, P.: Future European emission standards for vehicles: the importance of the UNECE Particle Measurement Programme, Biomarkers, 14, 29-33, https://doi.org/10.1080/13547500902965393, 2009.

May, A. A., Nguyen, N. T., Presto, A. A., Gordon, T. D., Lipsky, E. M., Karve, M., Gutierrez, A., Robertson, W. H., Zhang, M., Brandow, C., Chang, O., Chen, S. Y., Cicero-Fernandez, P., Dinkins, L., Fuentes, M., Huang, S. M., Ling, R., Long, J., Maddox, C., Massetti, J., McCauley, E., Miguel, A., Na, K., Ong, R., Pang, Y. B., Rieger, P., Sax, T., Truong, T., Vo, T., Chattopadhyay, S., Maldonado, H., Maricq, M. M., and Robinson, A.
L.: Gas- and particle-phase primary emissions from in-use, onroad gasoline and diesel vehicles, Atmos. Environ., 88, 247-260, https://doi.org/10.1016/j.atmosenv.2014.01.046, 2014.

Mendoza-Villafuerte, P., Suarez-Bertoa, R., Giechaskiel, B., Riccobono, F., Bulgheroni, C., Astorga, C., and Perujo, A.: $\mathrm{NO}_{x}, \mathrm{NH}_{3}, \mathrm{~N}_{2} \mathrm{O}$ and $\mathrm{PN}$ real driving emissions from a Euro VI heavy-duty vehicle. Impact of regulatory on-road test conditions on emissions, Sci. Total Environ., 609, 546-555, https://doi.org/10.1016/j.scitotenv.2017.07.168, 2017.

Moody, A. and Tate, J.: In Service $\mathrm{CO}_{2}$ and $\mathrm{NO}_{X}$ Emissions of Euro 6/VI Cars, Light-and Heavy-dutygoods Vehicles in Real London driving: Taking the Road into the Laboratory, Journal of Earth Sciences and Geotechnical Engineering, 7, 51-62, 2017.

Pirjola, L., Dittrich, A., Niemi, J. V., Saarikoski, S., Timonen, H., Kuuluvainen, H., Jarvinen, A., Kousa, A., Ronkko, T., and Hillamo, R.: Physical and Chemical Characterization of Real-World Particle Number and Mass Emissions from City Buses in Finland, Environ. Sci. Technol., 50, 294-304, https://doi.org/10.1021/acs.est.5b04105, 2016.

Pirjola, L., Niemi, J. V., Saarikoski, S., Aurela, M., Enroth, J., Carbone, S., Saarnio, K., Kuuluvainen, H., Kousa, A., Ronkko, T., and Hillamo, R.: Physical and chemical characterization of urban winter-time aerosols by mobile measurements in Helsinki, Finland, Atmos. Environ., 158, 60-75, https://doi.org/10.1016/j.atmosenv.2017.03.028, 2017.

Preble, C., Cados, T., Harley, R., and Kirchstetter, T.: Impacts of Aging Emission Control Systems on In-Use Heavy-Duty Diesel Truck Emission Rates, American Geophysical Union Fall Meeting, 11-15 December 2017, New Orleans, Louisiana, 2017.

Preble, C. V., Dallmann, T. R., Kreisberg, N. M., Hering, S. V., Harley, R. A., and Kirchstetter, T. W.: Effects of Particle Filters and Selective Catalytic Reduction on Heavy-Duty Diesel Drayage Truck Emissions at the Port of Oakland, Environ. Sci. Technol., 49, 8864-8871, https://doi.org/10.1021/acs.est.5b01117, 2015.

Preble, C. V., Cados, T. E., Harley, R. A., and Kirchstetter, T. W.: In-Use Performance and Durability of Particle Filters on HeavyDuty Diesel Trucks, Environ. Sci. Technol., 52, 11913-11921, https://doi.org/10.1021/acs.est.8b02977, 2018.

Quiros, D. C., Hu, S. H., Hu, S. S., Lee, E. S., Sardar, S., Wang, X. L., Olfert, J. S., Jung, H. J. S., Zhu, Y. F., and Huai, T.: Particle effective density and mass during steady-state operation of GDI, PFI, and diesel passenger cars, J. Aerosol Sci., 83, 39-54, https://doi.org/10.1016/j.jaerosci.2014.12.004, 2015.

Quiros, D. C., Thiruvengadam, A., Pradhan, S., Besch, M., Thiruvengadam, P., Demirgok, B., Carder, D., Oshinuga, A., Huai, $\mathrm{T}$., and $\mathrm{Hu}, \mathrm{S} .:$ Real-world emissions from modern heavy-duty diesel, natural gas, and hybrid diesel trucks operating along major California freight corridors, Emission Control Science and Technology, 2, 156-172, https://doi.org/10.1007/s40825016-0044-0, 2016.

Quiros, D. C., Smith, J. D., Ham, W. A., Robertson, W. H., Huai, T., Ayala, A., and Hu, S.: Deriving fuel-based emission factor thresholds to interpret heavy-duty vehicle roadside plume measurements, J. Air Waste Manage., 68, 969-987, https://doi.org/10.1080/10962247.2018.1460637, 2018.

Rexeis, M., Röck, M., and Hausberger, S.: Comparison of Fuel Consumption and Emissions for Representative Heavy-Duty Vehicles in Europe, Trans. Res. B., The National Academies of 
Sciences, Engineering, and Medicine, Washington, DC, 63 pp., 2018.

Ristimaki, J., Vaaraslahti, K., Lappi, M., and Keskinen, J.: Hydrocarbon condensation in heavy-duty diesel exhaust, Environ. Sci. Technol., 41, 6397-6402, https://doi.org/10.1021/es0624319, 2007.

Robinson, A. L., Donahue, N. M., Shrivastava, M. K., Weitkamp, E. A., Sage, A. M., Grieshop, A. P., Lane, T. E., Pierce, J. R., and Pandis, S. N.: Rethinking organic aerosols: semivolatile emissions and photochemical aging, Science, 315, 1259-1262, https://doi.org/10.1126/science.1133061, 2007.

Rymaniak, L., Ziolkowski, A., and Gallas, D.: Particle number and particulate mass emissions of heavy-duty vehicles in real operating conditions, MATEC Web of Conferences, 00025, https://doi.org/10.1051/matecconf/201711800025, 2017.

Sakurai, H., Park, K., McMurry, P. H., Zarling, D. D., Kittelson, D. B., and Ziemann, P. J.: Size-dependent mixing characteristics of volatile and nonvolatile components in diesel exhaust aerosols, Environ. Sci. Technol., 37, 5487-5495, https://doi.org/10.1021/es034362t, 2003a.

Sakurai, H., Tobias, H. J., Park, K., Zarling, D., Docherty, K. S., Kittelson, D. B., McMurry, P. H., and Ziemann, P. J.: On-line measurements of diesel nanoparticle composition and volatility, Atmos. Environ., 37, 1199-1210, https://doi.org/10.1016/S13522310(02)01017-8, 2003b.

Smit, R., Keramydas, C., Ntziachristos, L., Lo, T. S., Ng, K. L., Wong, H. L. A., and Wong, C.: Evaluation of real-world gaseous emissions performance of SCR and DPF bus retrofits, Environ. Sci. Technol., 53, 4440-4449, https://doi.org/10.1021/acs.est.8b07223, 2019.

Tan, Y., Henderick, P., Yoon, S., Herner, J., Montes, T., Boriboonsomsin, K., Johnson, K., Scora, G., Sandez, D., and Durbin, T. D.: On-Board Sensor-Based $\mathrm{NO}_{x}$ Emissions from HeavyDuty Diesel Vehicles, Environ. Sci. Technol., 53, 5504-5511, https://doi.org/10.1021/acs.est.8b07048, 2019.

Thiruvengadam, A., Besch, M. C., Carder, D. K., Oshinuga, A., and Gautam, M.: Influence of real-world engine load conditions on nanoparticle emissions from a DPF and SCR equipped heavy-duty diesel engine, Environ. Sci. Technol., 46, 1907-1913, https://doi.org/10.1021/es203079n, 2012.

Thiruvengadam, A., Besch, M. C., Thiruvengadam, P., Pradhan, S., Carder, D., Kappanna, H., Gautam, M., Oshinuga, A., Hogo, H., and Miyasato, M.: Emission rates of regulated pollutants from current technology heavy-duty diesel and natural gas goods movement vehicles, Environ. Sci. Technol., 49, 5236-5244, https://doi.org/10.1021/acs.est.5b00943, 2015.

Vaaraslahti, K., Virtanen, A., Ristimaki, J., and Keskinen, J.: Nucleation mode formation in heavy-duty diesel exhaust with and without a particulate filter, Environ. Sci. Technol., 38, 48844890, https://doi.org/10.1021/es0353255, 2004.

Van Setten, B. A., Makkee, M., and Moulijn, J. A.: Science and technology of catalytic diesel particulate filters, Cataly. Rev., 43, 489-564, https://doi.org/10.1081/CR-120001810, 2001.

Vojtisek-Lom, M., Pechout, M., Dittrich, L., Beranek, V., Kotek, M., Schwarz, J., Vodicka, P., Milcova, A., Rossnerova, A., Ambroz, A., and Topinka, J.: Polycyclic aromatic hydrocarbons (PAH) and their genotoxicity in exhaust emissions from a diesel engine during extended low-load operation on diesel and biodiesel fuels, Atmos. Environ., 109, 9-18, https://doi.org/10.1016/j.atmosenv.2015.02.077, 2015.

Wang, T., Quiros, D. C., Thiruvengadam, A., Pradhan, S., Hu, S., Huai, T., Lee, E. S., and Zhu, Y.: Total Particle Number Emissions from Modern Diesel, Natural Gas, and Hybrid Heavy-Duty Vehicles During On-Road Operation, Environ. Sci. Technol., 51, 6990-6998, https://doi.org/10.1021/acs.est.6b06464, 2017.

Watne, A. K., Psichoudaki, M., Ljungström, E., Le Breton, M., Hallquist, M., Jerksjö, M., Fallgren, H., Jutterström, S., and Hallquist, ̊. M.: Fresh and Oxidized Emissions from In-Use Transit Buses Running on Diesel, Biodiesel, and CNG, Environ. Sci. Technol., 52, 7720-7728, https://doi.org/10.1021/acs.est.8b01394, 2018.

Williams, M. and Minjares, R.: A technical summary of Euro 6/VI vehicle emission standards, International Council for Clean Transportation (ICCT), Washington, DC, available at: https://theicct.org/sites/default/files/publications/ICCT_ Euro6-VI_briefing_june2016.pdf (last access: 10 July 2017), 2016.

Zavala, M., Molina, L. T., Yacovitch, T. I., Fortner, E. C., Roscioli, J. R., Floerchinger, C., Herndon, S. C., Kolb, C. E., Knighton, W. B., Paramo, V. H., Zirath, S., Mejía, J. A., and Jazcilevich, A.: Emission factors of black carbon and co-pollutants from diesel vehicles in Mexico City, Atmos. Chem. Phys., 17, 15293-15305, https://doi.org/10.5194/acp-17-15293-2017, 2017.

Zhang, S. J., Wu, Y., Liu, H., Huang, R. K., Yang, L. H. Z., Li, Z. H., $\mathrm{Fu}, \mathrm{L}$. X., and Hao, J. M.: Real-world fuel consumption and $\mathrm{CO}_{2}$ emissions of urban public buses in Beijing, Appl. Energ., 113, 1645-1655, https://doi.org/10.1016/j.apenergy.2013.09.017, 2014.

Zheng, Z., Johnson, K. C., Liu, Z., Durbin, T. D., Hu, S., Huai, T., Kittelson, D. B., and Jung, H. S.: Investigation of solid particle number measurement: Existence and nature of sub-23 nm particles under PMP methodology, J. Aerosol Sci., 42, 883-897, https://doi.org/10.1016/j.jaerosci.2011.08.003, 2011.

Zheng, Z., Durbin, T. D., Xue, J., Johnson, K. C., Li, Y., Hu, S., Huai, T., Ayala, A., Kittelson, D. B., and Jung, H. S.: Comparison of particle mass and solid particle number (SPN) emissions from a heavy-duty diesel vehicle under on-road driving conditions and a standard testing cycle, Environ. Sci. Technol., 48, 1779-1786, https://doi.org/10.1021/es403578b, 2014.

Zheng, Z. Q., Durbin, T. D., Karavalakis, G., Johnson, K. C., Chaudhary, A., Cocker, D. R., Herner, J. D., Robertson, W. H., Huai, T., Ayala, A., Kittelson, D. B., and Jung, H. S.: Nature of Sub-23-nm Particles Downstream of the European Particle Measurement Programme (PMP)-Compliant System: A Real-Time Data Perspective, Aerosol Sci. Tech., 46, 886-896, https://doi.org/10.1080/02786826.2012.679167, 2012.

Zhu, Y. F., Hinds, W. C., Kim, S., Shen, S., and Sioutas, C.: Study of ultrafine particles near a major highway with heavy-duty diesel traffic, Atmos. Environ., 36, 4323-4335, https://doi.org/10.1016/S1352-2310(02)00354-0, 2002. 